\title{
Flexible Credit Line - Operational Guidance Note
}




\section{FLEXIBLE CREDIT LINE- OPERATIONAL GUIDANCE} NOTE

IMF staff regularly produces papers proposing new IMF policies, exploring options for reform, or reviewing existing IMF policies and operations. The Report prepared by IMF staff and completed on July 11, 2018, has been released.

The staff report was issued to the Executive Board for information. The report was prepared by IMF staff. The views expressed in this paper are those of the IMF staff and do not necessarily represent the views of the IMF's Executive Board.

The IMF's transparency policy allows for the deletion of market-sensitive information and premature disclosure of the authorities' policy intentions in published staff reports and other documents.

Electronic copies of IMF Policy Papers

are available to the public from

http://www.imf.org/external/pp/ppindex.aspx

\section{International Monetary Fund Washington, D.C.}




\section{INTERNATIONAL MONETARY FUND}

July 11,2018

\section{FLEXIBLE CREDIT LINE--OPERATIONAL GUIDANCE NOTE}

\section{EXECUTIVE SUMMARY}

This note provides general guidance on the use of the Flexible Credit Line ( $\mathrm{FCL}$ ). After an overview of the instrument, explaining its specific nature, the operational issues are grouped into three areas:

- an outline of the process and specific steps that need to be followed if a member expresses interest in an arrangement;

- guidance on determining qualification of a member; and

- a how-to guide for determining appropriate access levels.

The note is an aid to the implementation of the policy and its underlying principles. If there is any instance in which a provision of the guidance note or its implementation conflicts with Board policy, Board policy prevails. It will be revised as needed, for example following relevant policy reviews. 


\section{Approved By \\ Prepared by the Strategy, Policy, and Review Department in \\ Martin Mühleisen consultation with the Legal and Finance Departments}

\section{CONTENTS}

INTRODUCTION $\underline{3}$

OVERVIEW OF THE FCL $\underline{3}$

PROCESS $\underline{6}$

DETERMINING QUALIFICATION 13

JUSTIFICATION OF ACCESS 14

\section{FIGURE}

1. Timeline of FCL Application Process 10

\section{ANNEXES}

I. FCL and PLL Qualification Assessment $\underline{16}$

II. Determining Access on a Precautionary Basis $\underline{24}$

III. Index of External Economic Stress $\underline{29}$

IV. A Framework for Comparing Access Assumptions $\underline{34}$

V. Staff Documents for the Executive Board on the Use of FCL Resources $\underline{38}$

VI. Expedited Procedures $\underline{41}$

VII. Synchronized Approval of Flexible Credit Lines for Multiple Countries 42 


\section{INTRODUCTION}

1. The Flexible Credit Line ( $F C L)$ was introduced as part of a package of reforms to the Fund's lending facilities in March 2009 and its design was further refined in August 2010 and in the 2014 and 2017 Reviews of the policy. ${ }^{1}$ The following provides operational guidance and further background information on the FCL. SPR (the Lending Policy Division), FIN, and LEG stand ready to clarify any further questions departments may have on the $\mathrm{FCL}$ or other aspects of the reforms to lending and conditionality.

\section{OVERVIEW OF THE FCL}

2. The FCL is designed to provide a credit line with large and upfront financing to members with very strong fundamentals and institutional policy frameworks that have sustained track records of implementing very strong policies and remain committed to maintaining such policies in the future. Access under the $F C L$ is provided under an $F C L$ arrangement. ${ }^{2}$ As access to the $\mathrm{FCL}$ is available only to those members that meet strict qualification criteria, drawings under it are not tied to ex-post conditionality. The $F C L$ is designed to be flexible: (i) access is uncapped and funds are available upfront; (ii) grace period and repayment terms are long (31/4-5 years, starting on the date of each purchase) relative to alternative contingent financing; (iii) successor arrangements are unrestricted; ${ }^{3}$ and (iv) the FCL can be used for either contingent (precautionary) or actual balance of payments (BoP) needs.

- Approval (FCL decision, paragraph 6(a)). ${ }^{4} \mathrm{An} \mathrm{FCL}$ arrangement is approved following a confidential request from a member (next section). There is no list of members that pre-qualify for the FCL. Only if a country expresses an interest in requesting an FCL arrangement may staff assess in a confidential and preliminary way whether a member might qualify. When management decides that access to Fund resources under the FCL may be appropriate, it will promptly consult with the Executive Board at an informal meeting. A concise staff note setting out the basis on which approval could be recommended is provided to the Executive Board for this meeting. This note includes (i) a rigorous assessment of the member's actual or potential need for Fund resources and repayment capacity, and (ii) an assessment of the impact of the arrangement on Fund liquidity in cases where it is contemplated that access would exceed 575

\footnotetext{
${ }^{1}$ See GRA Lending Toolkit and Conditionality_Reform Proposals; The IMF's Mandate-The Future Financing Role: Reform Proposals and Revised Reform Proposals; the 2011 Review of the Flexible Credit Line and Precautionary Credit Line; the 2014 Review of the Flexible Credit Line, the Precautionary and Liquidity Line, and the Rapid Financing Instrument, including a follow-up paper on Specific Proposals; and the 2017 paper on the Adequacy of the Global Financial Safety Net-Review of the Flexible Credit Line and Precautionary and Liquidity Line, and Proposals for Toolkit Reform; and Revised Proposals following that paper.

2 Some terminology: established as a window in the Fund's credit tranches, the FCL is a financing instrument, and not a stand-alone facility, as is the case with the EFF. Access to Fund resources is provided under an FCL arrangement.

${ }^{3}$ Successive FCL arrangements may be approved, provided the member continues to meet the qualification criteria.

${ }^{4}$ All references to the FCL decision refer to Decision No. 14283-(09/29), adopted March 24, 2009, as amended by Decision No. 14714-(10/83), adopted August 30, 2010, and Decision No. 15593-(14/46), adopted May $21,2014$.
} 
percent of quota or SDR 10 billion, whichever is lower. A formal decision approving an FCL arrangement is then taken by the Executive Board at a subsequent Board meeting on the basis of the member's written request outlining its policy plans, a staff report assessing the member's qualification and justifying access under the $\mathrm{FCL}$, and the Managing Director's recommendation.

- Length (FCL decision, paragraph 5(a)). An FCL arrangement may be approved for one year or two years (the choice is binary; no other periods are possible) with the objective of completion of a mid-term review immediately prior to the lapse of the first twelve months of a two-year $\mathrm{FCL}$ arrangement. For FCL arrangements with a two-year duration, no purchase can be made after one year has elapsed from the date of approval until completion of an Executive Board review of the member's policies aimed at ascertaining the member's continued adherence to the qualification criteria (see $\llbracket 4$ below for a description of the mid-term review). Successive $\mathrm{FCL}$ arrangements may be approved for the member, provided that the qualification criteria continue to be met.

- Access under the FCL is uncapped, and it can be changed (augmented or reduced at the member's request, subject to Board approval) during the time of the arrangement subject to the member's continued qualification. The exceptional access policy does not apply to the FCL (i.e., access under the FCL above the normal access limits of 145 percent of quota annually and 435 percent of quota cumulative does not trigger the exceptional access policy), although its approval procedures are substantively similar to those under the exceptional access framework as discussed below (Decision No. 14064-(08/18), paragraph 2).

- Phasing (FCL decision, paragraphs 4 and 5(b)). The entire amount of requested access is available upon approval of the $\mathrm{FCL}$ arrangement and remains available throughout the arrangement period (subject to the completion of the mid-term review for two-year arrangements). The arrangement can be requested on a precautionary basis or to address an actual BoP need. The member has the option of making one or multiple purchases at any time during the term of the arrangement. ${ }^{5}$ The $\mathrm{FCL}$ arrangement would expire upon the earlier of (i) the expiration of the approved term of the arrangement; (ii) the purchase of the full amount of approved access under the arrangement; or (iii) the cancellation of the arrangement by the member.

- Conditionality (FCL decision, paragraphs 2, 3, and 5(a)). In light of the qualification criteria, there is no traditional ex-post conditionality, as the track record of policy implementation is intended to provide assurances that appropriate corrective policies, if needed, would be implemented. For the same reason, prior actions are not needed. Similarly, no ex-post conditionality_only ex-ante conditionality (qualification criteria)—can be attached to the midterm review or the approval of successive FCL arrangements. Once an arrangement has expired,

\footnotetext{
${ }^{5}$ As is standard under Fund facilities, while the Fund would not challenge the ex-ante representation of a BoP need by a member for a purchase requested under an $\mathrm{FCL}$ arrangement (nor in practice has it done so ex post), the member's drawings would have to be commensurate with its actual BoP need at the time of a purchase, notwithstanding the available amount of approved access. The concept of BoP need relates to the existence of an above-the-line BoP deficit or an inadequate level of reserves (see Article $\mathrm{V}$, Section 3(b)).
} 
if there have been purchases under the arrangement, then the Fund will conduct post-program monitoring (PPM) as warranted in accordance with the PPM policy. ${ }^{6}$

- Exit. A staff assessment of risks and, to the extent possible, the authorities' exit prospects would be expected to be included at the time of the initial $\mathrm{FCL}$ request to justify the proposed duration of the arrangement (one year or two years) and at the same time help promote transparency and underpin exit expectations. The elaboration of the authorities' exit strategy should help reduce the likelihood of market surprises following subsequent changes in access, or outright exit from the use of the FCL. For two-year FCL arrangements, this would be complemented at the time of the mid-term review by an updated assessment by staff of the anticipated evolution of risks over the rest of the arrangement period. ${ }^{7}$ The exit strategy would be expected to include the following elements:

- A statement about exit contingent on the reduction of external risks. The statement should specify the external risks that are relevant and should be informed by the external economic stress index described below;

- A statement regarding any efforts the authorities intend to take to improve domestic resilience, where relevant;

- A statement on the expectation that access will decline in successor arrangements when the right conditions are in place. ${ }^{8}$ This would mention the contingencies under which a successor arrangement may be requested with lower access, or under which no successor request would be likely.

Any exit and risk discussion would unavoidably be subject to a high degree of uncertainty and should be carefully crafted to preserve the role of judgment, while avoiding any risk of adverse market reaction. Discussion of the authorities' exit strategy in the staff report, moreover, would also help inform the Board discussion of the access level, in terms of the evolution of risks, and if a successor arrangement is ultimately considered. The inclusion of the external economic stress

\footnotetext{
${ }^{6}$ See Guidance Note on Post Program Monitoring.

${ }^{7}$ Directors reiterated in the 2017 review that "FCL and PLL arrangements should continue to provide details on an exit strategy, including a statement on the expectations that access will normally decline when the right conditions (as set forth in BUFF/10/125) are in place, underpinned by a sound and transparent analysis of the risks facing the member country and the authorities' efforts to increase the country's resilience, in order to guide market expectations while ensuring that exit continues to be state-contingent." (Press Release No. 17/507).

8 In Public Information Notice No. 10/24 on The Fund's Mandate-The Future Financing Role-Reform Proposals, Directors agreed that, in addition to other relevant factors justifying lower access, access under the FCL would normally be expected to decline in successor arrangements whenever improvements in official and private financing prospects have reduced the member's potential or actual balance of payments needs in a sustained manner by the time the successor arrangement is requested. See also Public Information Notice No. 11/152 on the 2011 Review of the Flexible Credit Line and Precautionary Credit Line, Press Release No. 14/352 on the 2014 Review of the Flexible Credit Line, the Precautionary and Liquidity Line, and the Rapid Financing Instrument, and Press Release No. 17/507 on the Adequacy of the Global Financial Safety Net-Review of the Flexible Credit Line and Precautionary and Liquidity Line, and Proposals for Toolkit Reform.
} 
index in documents should also be useful in this regard (see Annex II and the broader discussion of access below).

- Financial terms (GRA Lending Toolkit and Conditionality_Reform Proposals, III(B), paragraph 16). Purchases under the $F C L$ are subject to the same financial terms (repayment period, surcharges, and charges) as SBAs. Unpurchased amounts are subject to the standard upwardsloping commitment fee schedule. ${ }^{9}$

- $\quad F C L$ resources and their treatment in reserves. Unpurchased amounts available under the FCL arrangement are not counted in gross reserves (as they are not yet created as an asset). However, there is space in the Reserves Data Template filed by SDDS subscribers to announce the availability of these as yet unpurchased credit line resources. ${ }^{10}$ Once purchased, FCL resources give rise to an increase in gross reserve assets, as well as external liabilities (with maturities corresponding to the timing of repurchases), which are to be reported in Sections I and II of the Reserves Data Template.

\section{PROCESS}

\section{If a member is interested in an FCL arrangement, the process is as follows.}

- Initial steps. The member should approach staff or management confidentially and indicate its interest in obtaining financing under the $\mathrm{FCL}$ arrangement. (A mission is not required to discuss a request for an $\mathrm{FCL}$ arrangement or to assess qualification. However, if the latest available Article IV consultation report is more than a year old, or if circumstances warrant, a fact-finding staff visit may be needed to assess FCL qualification.) Staff should strongly encourage members to do this on a confidential basis, as failure to qualify under the instrument could have negative effects on market sentiment. Any publicity ahead of Executive Board consideration could prejudice the member's case as the Board could see this as an attempt to unduly influence the outcome. Fund staff must treat the authorities' request as confidential and cannot discuss

\footnotetext{
${ }^{9}$ The marginal commitment fee is equal to 15 basis points for access up to 115 percent of quota, 30 basis points for access above 115 and up to 575 percent of quota, and 60 basis points for access above 575 percent of quota. By way of example, the effective commitment fee levied on a 500 percent of quota arrangement is 27 basis points ( 15 basis points on 115 percent of quota and 30 basis points on the remaining 385 percent of quota). The commitment fee is levied upon approval of the arrangement and refunded on a pro rata basis if drawings are made under the arrangement. If the arrangement is cancelled without being drawn in full, the commitment fee will be refunded based on available amounts for purchase at the time of cancellation and the remaining number of days in the current period.

10 In general, IMF arrangements are conditional lines of credit and thus should not be included in Section III of the Reserves Data Template. The FCL has conditions for access, which include qualification criteria that must be met before the credit line is approved. In FCL arrangements with a one-year duration, once the qualification criteria are met, the member can draw down funds throughout the entire one-year period of the arrangement. In two-year FCL arrangements however, continued access to resources during the second year is also subject to completion of a review. In light of the above, the undrawn amounts under one-year FCL arrangements should be included in Section III from approval to the maturity of the FCL arrangement. Undrawn amounts under two-year FCL arrangements should be included in Section III from approval up until the scheduled review date under the FCL. See International Reserves and Foreign Currency Liquidity: Guidelines for a Data Template, paragraphs 206-207 and 216.
} 
qualification publicly. ${ }^{11}$ Staff should wait for a formal expression of interest by the member (e.g. in the form of an email or other written communication with the mission chief or area department head) before initiating an assessment of qualification and developing staff's views on qualification. In the initial exploratory discussions, staff should enquire as to the nature of the balance of payments problems (actual or potential) that has resulted in the member requesting an FCL arrangement and the desired level of access (see section on access below). The length of the arrangement sought by the authorities and whether the arrangement is meant to be treated as precautionary should be clarified at an early stage. Once an expression of interest has been received, area departments should consult closely with SPR on the key elements and process for assessing qualification.

- Preliminary assessment of qualification. The country team should then begin to prepare a confidential preliminary assessment of the member's qualification under the FCL. The staff can discuss the qualification criteria with the member, but they should make clear that it is the Executive Board that takes final decisions on qualification. Staff should take care to ensure that qualification is thoroughly assessed (see the discussion of qualification below and Annex I) and done in an evenhanded way. From this perspective, area department teams should consult early on with SPR, as well as FIN, LEG, and other functional departments as necessary, to seek guidance on qualification.

- Support from other creditors and consultation with Regional Financing Arrangements (RFAs). The FCL decision requires that when support from other creditors is likely to be important in helping a member address its BoP difficulties, staff will consult with key creditors (official or private sector) as appropriate to inform an assessment of access (FCL decision, paragraph 6(a)(ii)). In this case, the standard informal Board engagement (noted below), which would include a preliminary assessment of access, would likely take place after discussions with creditors. Consultation with other creditors could for example be envisaged when (i) there are sizeable remaining financing gaps that need to be filled by other creditors (usually official creditors); or (ii) the authorities are requesting precautionary support from both the IMF and other providers of financing, such as a Regional Financing Arrangement (RFA). ${ }^{12}$ Such consultations would be limited to sharing preliminary information at a technical level and would

\footnotetext{
${ }^{11}$ In case of a leak concerning an expression of interest by a member, staff would normally refrain from any comment, as per current Fund practice on press leaks. COM guidance should be sought as needed.

12 In the case of financing support by multilaterals (e.g., for members of a currency union and/or where a Regional Financing Arrangement is involved), staff should coordinate with the requesting member and the relevant multilaterals to ensure that these creditors' own internal rules and procedures, as applicable, do not conflict with the Fund's policies on the financial assistance request and communication strategy. See for example Program Design in Currency Unions (March 2018). In any case, these considerations should in no way delay prompt communications to the Board or prejudge its assessment of the member's request. Consultations with co-financiers will make clear that any discussions are ad referendum of decisions on the financing request by the Executive Board, and safeguards will be put in place to ensure confidentiality.
} 
not include sharing of the staff note for the informal Board meeting. ${ }^{13}$ In general, specified Board documents may be shared with RFAs that are co-financiers pursuant to established Fund policy. ${ }^{14}$ When sharing of Board documents is warranted, such sharing with RFAs is done via SEC. Country authorities should be informed and consent (in advance) of planned contacts with other creditors.

- Informal Board meeting "to engage" and staff note. If management decides that access to Fund resources under the FCL may be appropriate, it will promptly consult the Board in an informal (restricted) Board meeting. A concise staff note should set out the basis on which approval could be recommended. It is envisaged that the staff note be more succinct than the subsequent staff report on the formal request for an arrangement, as the informal Board meeting does not replace the broader discussion at the time of the formal request. The note would normally include a preliminary assessment of qualification and a discussion of the appropriateness of the proposed level of access, including a rigorous assessment of the member's actual or potential need and repayment capacity as well as of the impact of the arrangement on Fund liquidity for access requests above 575 percent of quota or SDR 10 billion, whichever is lower (FCL decision, paragraph 6(a)(iii)) (details on the staff note are set out in Annex $V$ ). Recent practice has been to treat the staff note as strictly confidential. Following consultation with the Board at the informal meeting, if there are concerns about a marketsensitive leak/misinformation regarding the $\mathrm{FCL}$ request, a press release could be issued indicating the authorities' interest and management's intention to recommend Board approval of the FCL arrangement. The press release would take special care not to prejudge the Board's final decision on an FCL arrangement.

- Timing of Article IV consultation. The FCL decision states that "a very positive assessment of the member's policies by the Executive Board in the context of the most recent Article IV consultations" is part of the qualification assessment framework. The Board has endorsed the principle that the consideration of Article IV consultations be timed sufficiently early to allow the Board's most recent assessment of the member's policies to be fully integrated into the assessment of qualification in the context of approval of or reviews under FCL arrangements. ${ }^{15}$ This principle should apply equally to mandatory financial stability assessments, which are legally part of the Article IV consultations, and in general to other documents that feed into Article IV consultations, such as voluntary FSAPs and ROSCs. In practice, this would normally mean holding the Article IV discussion at least 4-6 weeks prior to a formal Board meeting for either the approval of, or review under, an FCL arrangement to ensure the Board's appraisal can be incorporated in the staff report sent for review and management clearance.

\footnotetext{
${ }^{13}$ Management may authorize the sharing of preliminary program information at a technical level with RFAs or other parties that are co-financiers or creditors. See Collaboration Between Regional Financing Agreements and the IMF, paragraph 37.

${ }^{14}$ See The Exchange of Documents Between the Fund and Regional Financing Arrangements.

15 "Directors reaffirmed the importance of concluding Article IV consultations prior to FCL and PLL arrangements' approvals or reviews so as to incorporate the Board's most recent assessment of a member's economic performance in the relevant qualification assessments." Press Release: IMF Executive Board Discusses FCL, PLL, and RFI Review.
} 
- Preparation of the staff report. Details on the content of the staff report are set out in Annex V. A mission is not normally expected. However, in some cases, a mission may be deemed necessary (prior to the informal Board meeting) to further assess qualification or to finalize determination of access levels or to clarify the authorities' intentions regarding policy goals and strategies. As the staff report would normally reflect discussions at the informal Board meeting, SPR's clearance of the staff report would only be provided after the conclusion of that meeting.

- The authorities' written communication. The written, signed communication requesting an FCL arrangement should describe macroeconomic conditions and the authorities' broad policy goals and strategies for the term of the arrangement, as well as the reasons inducing the member to request Fund assistance under the FCL (FCL decision, paragraph 6(a)(iv)). The authorities would also need to specify the nature of the BoP need and whether they intend to treat their access request on a precautionary basis. Members could add a reference to exit expectations in their written communication (see the discussion of exit strategy in 12 ). The authorities' note should explain how they will remain committed to very strong economic policies (as expected under the $\mathrm{FCL}$ ) and respond appropriately to any shocks that may arise. ${ }^{16}$ Cross-referencing material published separately by the authorities would be appropriate (see, for example, the Mexican Authorities' Written Communication on pages 31 and 32 of the Staff Report ${ }^{17}$ ). Note that this written communication is not a Letter of Intent for the purpose of monitoring policy commitments. This letter should be dated after the informal Board meeting.

- Central bank safeguards. A member requesting an FCL arrangement is not subject to the Fund's policy on safeguards assessments applicable to other arrangements. However, at the time of making a formal written request for an $\mathrm{FCL}$ arrangement, the member will provide authorization for Fund staff to have access to the most recently completed annual independent audit of its central bank's financial statements, whether or not the audit is published. This will include authorizing its central bank's external auditors to discuss the audit findings with Fund staff, including any written observations by the external auditors regarding the weaknesses observed in internal controls ( $\mathrm{FCL}$ decision, paragraph 6(b)).${ }^{18}$ In addition, staff would duly raise and discuss the emergence of any significant safeguards issues arising from the latest published external audit report on the central banks' financial statements in the context of mid-term reviews (see further guidance below ). Area department teams are encouraged to consult early on with FIN staff on safeguards requirements, including ahead of mid-term reviews.

\footnotetext{
${ }^{16}$ Country teams should be mindful of the electoral cycle and, where possible, should seek to delink the timing of a request for a new arrangement from the electoral cycle. Where it is not possible to delink the request in this way, staff should seek assurances from electoral candidates that the very strong policies and policy frameworks will be maintained. Such assurances are an important forward-looking safeguard for the $\mathrm{FCL}$, where a member has upfront access to the full financing, without ex-post conditionality.

17 IMF Country Report No. 09/126.

${ }^{18}$ See FIN Operational Guidelines for Safeguards Assessments (March 2017) for the safeguards requirements under the FCL.
}

(continued) 
- Interdepartmental review and circulation periods. Normal interdepartmental review procedures and circulation periods apply to the FCL. The current circulation period is two weeks for the formal Executive Board meeting, and recent practice for the informal Board meeting has been to allow for one-week circulation. The circulation period for informal Board Meetings is thereby similar to that for informal Board Discussions on Exceptional Access cases. ${ }^{19}$ Where needed-such as an urgent actual balance of payments need or risk of leaks that could be market destabilizing-FCL-specific expedited procedures can be followed (Annex VI). ${ }^{20}$

- Formal Executive Board meeting. The Board considers and may approve an FCL arrangement based on the member's written request outlined above and the staff report. As for other Executive Board meetings on the Use of Fund Resources, staff will provide a Summing Up (for internal use) and a Chairman's Statement, which will be published subject to the member's consent.

- Activation of credit line. The credit line is open on approval of the arrangement. Prior to approval of the FCL arrangement, FIN will need to receive authorization from the authorities to debit the member's SDR account for payment of the commitment fee, which is due upon approval of the FCL arrangement.

- Transparency. The Managing Director will generally not recommend that the Executive Board approve a request to use Fund resources under the $\mathrm{FCL}$ unless the member consents to the publication of the associated staff report. ${ }^{21}$ Thus, it is expected that the staff report, as well as the authorities' written communication requesting an FCL arrangement and outlining the member's policy goals, will be published shortly after the Board's approval of the arrangement. The Fund's Transparency Policy, including the rules on corrections and deletions, applies.

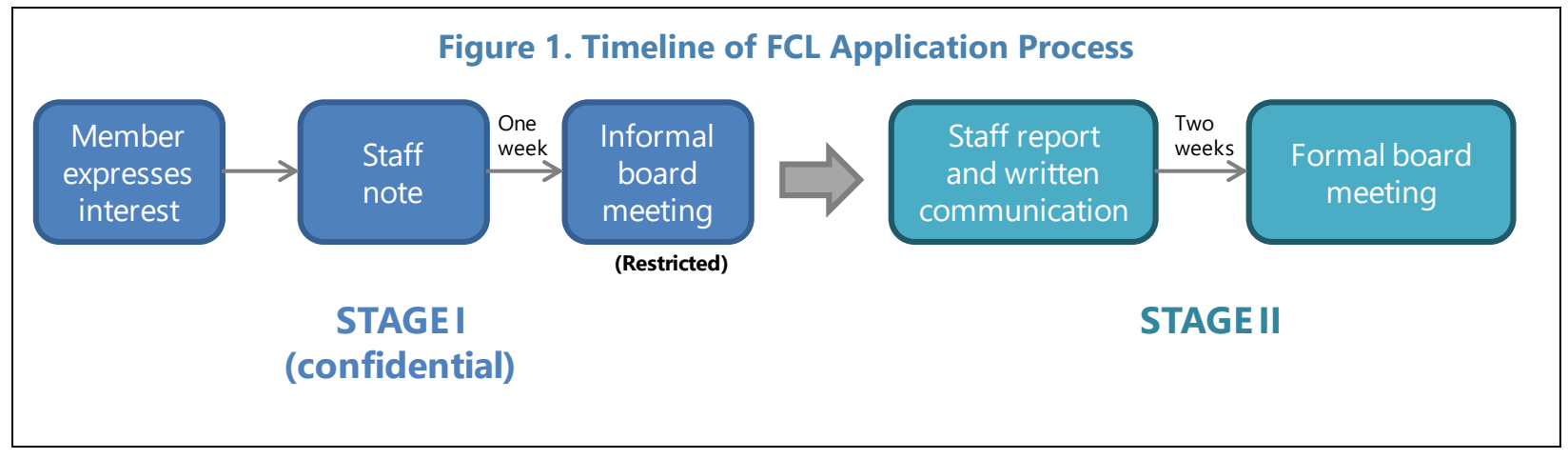

4. Beyond the request, the following procedures would apply for the making of purchases, the mid-term review, expiration of an arrangement, and the request of a successor arrangement:

\footnotetext{
19 "Access policy in Capital Account Crises-Modifications to the Supplemental Reserve Facility (SRF) and Follow-up Issues Related to Exceptional Access Policy," 2003, and "Review of Exceptional Access Policy," 2004.

20 Since the FCL Decision (see example Annex IV) provides for its own expedited procedures, the provisions of Emergency Financing Mechanism procedures do not apply to requests for an FCL arrangement.

21 Transparency Policy Decision, paragraph 4b, Decision No. 15420-(13/61), June 24, 2013.
} 
- Purchases. Should the member decide to purchase under the FCL arrangement, FIN would need to receive official communication, via SWIFT, from the fiscal agency of the member requesting a purchase under the $\mathrm{FCL}$ arrangement, specifying the amount of the purchase and representing an actual balance of payments need-a standard requirement for any purchases under the IMF's General Resources Account. FIN would immediately contact the authorities to determine the earliest possible value date, the currency composition of the purchase, and other operational details in line with established guidelines and procedures. The member should be encouraged to disclose information about any purchases under an $\mathrm{FCL}$ arrangement as information on purchases under Fund arrangements is routinely publicly displayed on the Fund's external webpage (on financial transactions with member countries). Approval of a two-year FCL arrangement provides the member with purchase rights, which are not subject to ex-post conditionality, until the date of the scheduled mid-term review, which should be scheduled to take place immediately prior to the lapse of one year since the approval of the FCL arrangement (see next bullet). In the case of one-year arrangements, the approval of the $\mathrm{FCL}$ arrangement provides the member with such purchase rights for the entire period of the arrangement. If the $\mathrm{FCL}$ arrangement was requested on a precautionary basis upon approval, Executive Directors would normally be promptly informed ex post when a member has drawn under the $\mathrm{FCL}$ arrangement. This information would ideally be provided in a concise note discussing the latest developments leading to the emergence of the actual BoP need and corresponding purchase and the outlook. An updated financing needs and sources table will be included in the note, presenting the BoP need projections by the team for the remainder of the arrangement period, as well as an updated capacity to repay table. The note can either be sent to the Executive Board for information or as background for an informal briefing to the Executive Board after the drawing has taken place, as deemed necessary.

- Mid-term review. For two-year FCL arrangements, a mid-term review prior to the lapse of the first twelve months of the arrangement is required to assess whether the country still meets the qualification criteria for the FCL (FCL decision, paragraph 5(a)). The review should be scheduled with the objective of completion by the Executive Board immediately prior to the lapse of the one-year period or else the member could temporarily lose automatic access to Fund resources. Staff should prepare a concise staff report to inform the Board about recent developments, the expected evolution of risks over the remainder of the arrangement, policy initiatives, and a brief update assessing the country against the qualification criteria (see Annex $V$ for a description of the likely content of the report). Moreover, whenever the latest published external audit report on the central banks' financial statements points to the newly emergence of significant safeguards issues, these would be duly raised and discussed by staff in the context of the midterm review. To this effect, staff should consult with FIN promptly ahead of the mid-term review. Board approval of the review could be on a lapse of time basis. A mission will not normally be necessary to conduct a mid-term review, although the assessment of a member's continued qualification will benefit from the findings of recent routine staff visits or Article IV consultation 
missions. ${ }^{22}$ If there have been very substantial changes in policy strategies or goals, then a new letter from the member setting out their new strategies and goals should also be attached and discussed in the report. ${ }^{23}$ The staff report would be subject to the standard review process (with no Policy Note or Policy Consultation Meeting required) and should be circulated according to the normal circulation procedures-unless there is a case for expedited procedures (Annex VI).

- Changes in access. Members may request at any time a reduction or augmentation of access within an existing FCL arrangement. This could, for example, be requested the time of the mid-term review. All requests for changes in access should refer to the changes in the member's BoP needs and provide a justification for the requested change. While changes in access have occurred for all members with FCL arrangements, Poland provides a good example of external communication in the context of access reductions leading to the eventual full exit from $\mathrm{FCL}$ arrangements. ${ }^{24}$

- Expiration of FCL arrangements. With the nearing of the expiration of an FCL arrangement, staff or management could issue a factual press statement at the member's request noting the successful conclusion of the $\mathrm{FCL}$ arrangement. This could highlight the member's recent performance and the supporting role played by the $\mathrm{FCL}$ arrangement. In this circumstance-and in all situations where a press statement is proposed, including for example, when an arrangement is canceled by the authorities prior to its expiration-the press statement should be coordinated with COM and SPR to ensure that the impact of such communication on all members under FCL arrangements is taken into account in the communications strategy. Although there will be incentives to bolster the impression that countries are choosing not to seek a successor arrangement even though they qualify, it is important that press statements should not include any assessment of potential qualification for a successor FCL arrangement-a member's expression of interest in a successor FCL arrangement is subject to the same confidentiality requirement as the initial request and should follow the same process as set out in this guidance note and in GRA Lending Toolkit and Conditionality-Reform Proposals, III(B), paragraph 15 and FCL Decision, paragraph 6(a). In cases where a member is likely not to continue to qualify for an $\mathrm{FCL}$ (whether at the expiration of a current arrangement or in the context of a review), staff should begin discussions with the authorities well ahead of time when

\footnotetext{
22 If a staff visit precedes the mid-term review, standard review procedures for briefing memoranda apply (i.e., it should be circulated for comments to SPR, LEG, and FIN, and sent to Management for approval if there is a change in policy line or economic circumstances. If the area department and SPR agree there is no change, a one-page brief is adequate and should be circulated for information only.) According to the 2010 Decision on Consultation Cycles (Decision No. 14747-(10/96), as amended) when an FCL arrangement is approved for a member, that member shall be automatically placed on a 12-month consultation cycle subject to the procedures specified in paragraph 3 of such decision.

${ }^{23}$ This is because the FCL decision (paragraph 6(a)(iv)(I)) requires a written communication from the member at the time of the initial request outlining its policy goals and strategies for "at least the duration of the arrangement." Thus, should the member's policy goals and strategies evolve during the arrangement, a new letter clarifying such new policies and strategies will be required to complete the mid-term review.

${ }^{24}$ Following previous increases in access, Poland reduced access on three occasions before fully exiting the $\mathrm{FCL}$ arrangement in November 2017. See Press Releases No. 15/05 (new arrangement with lower access), No. 16/06 (reduction in access at time of a review), No. 17/11 (new arrangement with lower access), No. 17/418 (cancellation of arrangement).
} 
material concerns start arising. Most likely this would occur in the context of a regular staff visit or Article IV consultation mission to flag this as a possible outcome, with a view to incentivizing necessary policy adjustment or providing the authorities with sufficient time to prepare for exit. At the expiration of FCL arrangements, or in situations where the authorities cancel an arrangement prior to its expiration, as a courtesy and to the extent possible, staff would update the Board through the Secretary before commencing its standard public communication strategy.

- Cancellation of existing arrangement and request for successor arrangement. A request for a successor arrangement-for example during a protracted period of heightened risks-would follow the same procedures as for a first-time request. If the Board meeting for the request for a successor arrangement is before the expiration of the current arrangement, the current arrangement would need to be cancelled prior to its expiration. In this event, the authorities' written communication on a request for a successor $\mathrm{FCL}$ arrangement should include a statement about the member's decision to cancel the existing arrangement as of a specified date, which would usually be the date of approval of the new arrangement. ${ }^{25}$ In situations where the authorities desire to cancel the existing arrangement ahead of its expiration but do not wish to request a successor arrangement, a member can cancel an $\mathrm{FCL}$ arrangement through written notification to IMF management, preferably in the form of a formal letter signed by the authorities. The notice of cancellation must clearly specify the effective date of cancellation, which should not be earlier than the date of receipt of the letter by the Fund.

- Communication strategy. Careful communication will be an essential element of any FCL arrangement to provide forward guidance to market participants about the authorities' future use of the FCL and exit plans. A communication strategy should be developed with country authorities and should encompass not only the essential details of the instrument (and the rationale for its usage) but also the authorities' exit strategy.

\section{DETERMINING QUALIFICATION}

\section{Determining qualification is not a tick-the-box exercise against the criteria. Instead staff should make a judgment based on all of the following:}

- An assessment of whether the member (a) has very strong economic fundamentals and institutional policy frameworks; (b) is implementing — and has a sustained track record of implementing - very strong policies; and (c) remains committed to maintaining such policies in the future, all of which give confidence that the member will respond appropriately to the balance of payments difficulties that it is encountering or could encounter ( $F C L$ decision, paragraph 2). This assessment is the core of the qualification process.

\footnotetext{
${ }^{25}$ To ensure continuity between the predecessor $\mathrm{FCL}$ arrangement and the successor one, the written communication could note the member's decision to cancel the existing FCL arrangement with effect immediately prior to the approval of the new successor FCL arrangement.
}

(continued) 
- Staff should make clear that a very positive assessment of the member's policies was given in the context of the most recent Article IV consultations (FCL decision, paragraph 2).

- The relevant qualification criteria listed in Annex $1^{26}$ should be assessed by staff in the initial concise staff note to the Board and the staff report on the $\mathrm{FCL}$ arrangement request.

Nevertheless, it is recognized that these qualification criteria and the related indicators will need to take into account the great variety of members' circumstances and the uncertainties surrounding economic projections. Strong performance against all relevant criteria would not be necessary to secure qualification under the FCL. However, significant shortcomings on one or more of these criteria-unless there are compensating factors, including corrective policy measures underway-would generally signal that the member is not among the strong performers for whom the $\mathrm{FCL}$ is intended.

6. In circumstances where a member is assessed and judged not to qualify for the FCL, the Board would not be notified of such request. Thus, the only situation where the Board would be notified is when management decides that access under the FCL may be appropriate.

\section{JUSTIFICATION OF ACCESS}

\section{General Fund policy provides for access decisions in individual country cases to be} based on: (i) the member's actual or potential need for Fund resources taking into account other sources of financing and the desirability of maintaining a reasonable level of reserves (further details on determining the BoP need are covered in Annex II of GRA Lending Toolkit and ConditionalityReform Proposals); (ii) the member's capacity to repay the Fund, which takes into account the strength of its adjustment program, including the extent to which it will lead to a strengthening of the member's BoP by the time that repurchases begin to fall due; and (iii) the amount of the member's outstanding Fund credit and its record in using Fund resources in the past.

\section{Annexes II through IV describe in more detail the framework and relevant tools for} developing an access scenario for precautionary purposes. Justification for access under an actual BoP need would follow normal program guidelines. SPR reviewers and the Lending Policy Division in SPR can provide further guidance when needed. Poland's $2015 \mathrm{FCL}$ request provides an example of good practice for a precautionary request.

- Annex II provides a general framework for use by staff when considering access in a precautionary setting;

\footnotetext{
${ }^{26}$ On May 21, 2014, the Board approved a change in the seventh qualification criterion from "the absence of bank solvency problems that pose an immediate threat of a systemic banking crisis" to "sound financial system and the absence of solvency problems that may threaten systemic stability." This change applies to arrangements approved after May 21, 2014. Decision No. 155593 - (14/46). The Board also endorsed the use of indicators of institutional strength. To provide a more transparent and predictable basis for assessing whether a member meets the qualification criteria, the 2017 Review of the Flexible Credit Line and the Precautionary and Liquidity Line identified a core set of indicators with thresholds to be considered as part of the qualification assessment.
} 
- Annex III presents the methodology to calculate an external economic stress index ${ }^{27}$, which shows the evolution of the external environment as it pertains to the particular member with examples from the 2014 Review of the FCL, PLL, and RFI. This should be used to help guide access discussions; and,

- Annex IV presents an empirical method for comparing access assumptions across FCL cases and with historical experience. This method has been routinely implemented in FCL and PLL requests and helps improve transparency in access discussions.

27 The external economic stress index was endorsed by the Board in the 2014 Review, along with various metrics of reserve levels as set forth in Annexes III and IV. 


\section{Annex I. FCL and PLL Qualification Assessment}

1. This annex provides the key considerations for assessing qualification to access financing under the FCL and the PLL, with a view to promoting a predictable and evenhanded qualification process. The qualification criteria for the FCL and the PLL remain as endorsed by the Executive Board in 2014. ${ }^{1}$ However, to provide a more transparent and predictable basis for assessing whether a member meets the qualification criteria, the 2017 Review of the FCL and the PLL identified a core set of indicators with thresholds based on established analytical frameworks (e.g., metrics such as the Assessing Reserve Adequacy (ARA) and bottom-line assessments of a member's external position-see below). These core indicators are drawn from the set of indicators endorsed by the Executive Board in 2014 and do not obviate the need for judgment in the assessment of qualification.

2. The core of the qualification framework for the $F C L$ is an assessment that the member's economic fundamentals, institutional policy framework, and policies are very strong. These qualification criteria, together with a sustained track record of very strong policy implementation, would give the Fund confidence that the member would take appropriate corrective policy measures when facing an adverse shock, consistent with addressing the BoP problems it may be facing and with repaying the Fund. The member's policies must have been assessed very positively by the Executive Board in the context of the most recent Article IV consultations. As FCL resources can be used for any BoP problem and an FCL arrangement can be approved in the face of an actual or potential financing need, qualification for the FCL would not preclude circumstances where the member would need or plan to undertake policy adjustments.

3. The core of the qualification framework for the PLL is an assessment that the member's economic fundamentals, institutional policy framework, and policies are generally sound.

Those, together with a track record of sound policy implementation, would give the Fund confidence that the member will take the policy measures needed to reduce any remaining vulnerabilities and respond appropriately to any BoP problem it is encountering or might encounter, consistent with repaying the Fund. As a member qualifying under a PLL arrangement may still face remaining vulnerabilities (although not substantial) in a few areas, the qualification assessment for the PLL will be a crucial tool in identifying areas for prior actions and/or ex-post policy conditionality, as applicable under the PLL decision. The member's policies must have been assessed as generally positive by the Executive Board in the context of the most recent Article IV consultation.

\section{Qualification for the FCL and the PLL is based on nine specific qualification criteria as} set forth below. Any assessment of qualification involves judgment. Hence, the assessment of the qualification criteria will need to take into account the great variety of members' circumstances and the uncertainties that attend economic projections.

\footnotetext{
1 See "Review of the Flexible Credit Line, the Precautionary and Liquidity Line, and the Rapid Financing InstrumentSpecific Proposals-Annex I" sup. 2 and 3, endorsed by The Acting Chair's Summing Up, Executive Board Meeting $\underline{14 / 53}$ on June $11,2014$.
} 
- FCL. Very strong performance against all relevant criteria noted below would not be necessary to secure qualification. However, significant shortcomings on one or more of these criteria-unless there are compensating factors, including corrective policy measures underway-would generally signal that the member is not among the very strong performers for whom the FCL is intended.

- PLL. The member's performance under the nine qualification criteria will be assessed based on five broad qualification areas. The qualification standard is based on strong performance in most of the five qualification areas (i.e., three of five areas) noted below. Substantial underperformance in any area signals that the member does not qualify for a PLL. In addition, a member would not be qualified to use the PLL if any of the following circumstances apply: (i) sustained inability to access international capital markets, (ii) the need to undertake large macroeconomic or structural policy adjustments (unless such adjustment has already been set credibly in train before approval), (iii) a public debt position that is not sustainable in the medium term with a high probability, and (iv) widespread bank insolvencies.

\section{A. Qualification Criteria}

\section{For the FCL and PLL assessments, staff would rely primarily on the following nine} qualification criteria, including a set of relevant core indicators, to establish the strength of the member's underlying fundamentals and economic policies. For purposes of the PLL, the nine criteria are grouped under five broad qualification areas I-V. While PLL qualification assessments are based on the same set of underlying nine criteria, there is no precise "scoring" of the nine qualification criteria. Hence, as with the $\mathrm{FCL}$, the bottom-line assessment on each criterion will remain a judgment, guided by the relevant indicator. While the set of core indicators and their thresholds constitute a key element in determining whether the criteria are met, they do not obviate the need to consult other sources of information-including the broader set of Board-approved indicators-deemed relevant for the bottom-line assessment of any given criterion in a specific country context (Annex Tables 1 and 2):

\section{External Position and Market Access}

1. A sustainable external position. The core indicator requires the member's external position to have been assessed, in the most recent Board document (Article IV or ESR), as "broadly consistent", "moderately stronger (weaker)", "stronger", or "substantially stronger" than implied by fundamentals and desirable policies. This assessment implies that members with "weaker" or "substantially weaker external positions" would not meet the criterion. The asymmetry in the assessment follows the reasoning that "weaker" or "substantially weaker" external positions (e.g., high current account deficit or net foreign liabilities, overvalued exchange rate, etc.) constitute early warning indicators for impending BoP crises. In addition to the assessment of exchange rate misalignment, other relevant indicators would be: the debt-stabilizing noninterest current account balance; the level and composition of external debt; the level of net international reserves; and the level and composition of private sector external assets. 
2. A capital account position dominated by private flows. The core indicator requires public flows to account for less than half of a member's direct, portfolio, and other asset and liability flows, on average in the past three years. In addition to the composition of recent capital flows, an assessment of the International Investment Position is also relevant.

3. A track record of steady sovereign access to capital markets at favorable terms. The core indicator requires public sector issuance or guaranteeing of external bonds or disbursements of public and publicly-guaranteed external commercial loans in international markets during at least three of the last five years for which data are available, in a cumulative amount over that period equivalent to at least 50 percent of the country's Fund quota at the time of the assessment. The indicator also requires that the member did not, in staff's assessment, lose market access at any point in the last 12 months. Following the Fund's framework for loss of market access, deteriorating funding conditions and adverse changes in issuance patterns (volume, maturity, and frequency of issuance) that cannot be explained by funding needs would be indications that the member has lost market access. Other relevant indicators would be a comparison of spreads with comparator countries and relative performance of spreads during periods of global shocks.

4. When the arrangement is requested on a precautionary basis, a reserve position whichnotwithstanding potential BOP pressures that justify Fund assistance-remains relatively comfortable. The core indicator requires reserves to have been greater than 100 percent of the unadjusted Assessing Reserve Adequacy (ARA) metric on average over three (the current and the two previous) years, and not below 80 percent in any of these three years. By including a lower-but not an upper-threshold for reserves, the assessment follows the reasoning that excess reserve holdings, while possibly undesirable from a systemic perspective, do not constitute a vulnerability for the member. Other relevant indicators would include additional metrics (imports, short-term debt, monetary base, augmented ARA metrics) as relevant given the member's exchange rate regime and other factors. These other indicators could also be used instead of the unadjusted ARA metric, if the latter is deemed inadequate for judging the member's reserve position. This assessment should generally be reflected in recent Article IV reports.

\section{Fiscal Policy}

5. Sound public finances, including a sustainable public debt position determined by a rigorous and systematic debt sustainability analysis. The core indicator requires the member's public debt to be assessed as sustainable with a high probability. The high probability assessment would explicitly take into account risks to public finances not immediately visible in current public debt projections. In addition, discussions would cover the evolution of debt, as well as rollover and financing requirements under alternative scenarios (including an assessment of contingent liabilities, where appropriate) and stress tests. Relevant indicators may also include the recent evolution of fiscal balances in relation to the economy's cyclical position; the quality of any adjustment measures being considered; an assessment of medium-term plans anchoring fiscal policy outcomes; and an overall sound institutional budgetary framework as informed by recent fiscal ROSCs, where available. 


\section{Monetary Policy}

6. Low and stable inflation, in the context of a sound monetary and exchange rate policy framework. The core indicator requires the member to have maintained single-digit inflation over the past five years. The bottom-line assessment would consider if the member's performance is seen to reflect favorable external conditions and there are grounds to question its ability to maintain low inflation under normal circumstances. It would also consider persistent deviations from stated inflation targets, as well as sustained deflation, to the extent that it reflects deficiencies in the monetary policy framework. In addition to headline inflation, other relevant indicators would include the recent evolution of core inflation and inflation expectations; past and announced policy responses to inflationary shocks; the adequacy of monetary policy instruments to conduct monetary policy; accountability, transparency, and communication regarding policy objectives and policy responses.

\section{Financial Sector Soundness and Supervision}

7. Sound financial system and the absence of solvency problems that may threaten systemic stability. The core indicator requires the average capital adequacy ratio for the banking sector to be above regulatory thresholds, and that the most recent Article IV did not highlight significant solvency risks or recapitalization needs. In addition, a range of other indicators and available information may be combined to assess this criterion. In addition to compliance with regulatory requirements, the bottom-line assessment would consider also other financial soundness indicators. This would include measures of profitability and asset quality, as well as any relevant stress tests conducted by staff, or other analyses of market, credit, and liquidity risks facing banks based on recent FSAPs or other sources, to provide a forward-looking perspective. It would also reflect potential problems in large and systemic banks that may be masked by system-wide averages.

8. Effective financial sector supervision. The core indicator requires that the most recent FSAP or Article IV report did not raise substantial concerns regarding the supervisory framework. The bottom-line assessment would consider any significant changes in conditions since the latest FSAP. In addition, relevant modalities to consider would include an assessment of the legal and institutional framework, as well as the operational capacity, to respond promptly if bank interventions and resolution is warranted and if emergency liquidity assistance is needed.

\section{Data Adequacy}

9. Data transparency and integrity. The core indicator requires that the member is a Special Data Dissemination Standard (SDDS) subscriber or has made satisfactory progress toward meeting the SDDS requirements.

\section{The assessment of policy track record will be anchored in the same set of core}

indicators. Determination of whether a member meets the track record requirement would be guided by an assessment of the qualification criteria in each of the five most recent years. The 
bottom-line assessments on each criterion would follow the same approach as for the current year, including by drawing on additional information, e.g., the appropriateness of a member's policy response to past bouts of capital flow volatility, and the extent to which individual indicator outcomes reflect favorable external conditions. ${ }^{2}$

\section{B. Indicators of Institutional Strength}

7. Under the qualification frameworks for the FCL and the PLL, an eligible member should be assessed to have a very strong or sound institutional policy framework for the $\mathrm{FCL}$ and the PLL respectively. To complement the assessment of staff in this area, the following indicators could also be considered.

- Policy cyclicality. Relevant indicators to inform this judgment may include, for fiscal policy, the moving correlation between the cyclically-adjusted fiscal balance or government spending and cyclically-adjusted GDP, and for monetary policy, the moving correlation between the cyclicallyadjusted real short-term policy rate and cyclically-adjusted GDP. In countries with rigid exchange rate regimes, it may also be worth exploring the cyclicality of cash reserve requirements.

- Effective response to shocks. Relevant indicators to inform this judgment include government effectiveness and control of corruption from the Worldwide Governance Indicators. When doing so, staff should ensure that indicators are used consistently with the policy on third-party indicators. ${ }^{3}$ Also, in practice when working with (perception-based) third-party indicators on corruption in staff reports, country teams should refrain from using rankings. Staff should rely instead on point scores and consider presenting country scores relative to a range or an average of peers. Staff should also be mindful of the degree of uncertainty around reported point estimates when using these indicators. That is, the difference between a country's score in two different years or between two countries' scores in a single year can be statistically insignificant if their confidence intervals overlap.

\footnotetext{
${ }^{2}$ As in the case of the bottom-line assessment on the nine qualification criteria, very strong performance against all qualification criteria is not required.

3 See IMF Policy Paper on "Use of Third-Party Indicators in Fund Reports," November 2017.
} 
Annex I. Table 1. Summary of Broad Indicators for FCL and PLL Qualification Criteria

Criterion

1 Sustainable external position

2 Capital account position dominated by private flows

3 Track record of steady sovereign access to capital markets at favorable terms

4 Reserve position which-notwithstanding potential BoP pressures that justify Fund assistance-remains relatively comfortable (precautionary requests)

5 Sound public finances, including a sustainable public debt position determined by a rigorous and systematic debt sustainability analysis

6 Low and stable inflation, in the context of a sound monetary and exchange rate policy

7 Sound financial system and the absence of solvency problems that may threaten systemic stability

8 Effective financial sector supervision

9 Data transparency and integrity
Indicator

Gross external debt/GDP; including DSA assessment; debt-stabilizing noninterest current account deficit; net external debt/GDP; short-term gross external debt/GDP; share of bank, nonbank and public sector gross external debt.

FDI plus portfolio inflows as a share of total capital inflows; ratio of private holdings of external debt to gross external debt; and private foreign holdings of domestic debt/total domestic debt.

$E M B I$ spread; spread between country EMBI and $E M B I$ overall index (using latest observation and averages over previous five years); current yield on benchmark bonds; credit ratings; and last external issuance (details on amount issued/ original yield/maturity).

Ratio of reserves to: ARA metric, short-term debt (remaining maturity basis); short- term debt (remaining maturity basis) plus current account deficit; imports; and broad money.

Public sector debt-to-GDP ratio, and debt sustainability assessment; primary and overall fiscal balance (average for the last 3/5 years); structural fiscal balances and debt-stabilizing primary balance. Assessment of MT plans anchoring fiscal policy outcomes; and overall sound institutional budgetary framework as informed by recent fiscal ROSCs, where available.

Recent evolution of core and headline inflation and inflation expectations. Past and announced policy responses to inflationary shocks. Adequacy of monetary policy instruments to conduct monetary policy. Accountability, transparency, and communication regarding policy objectives and policy responses.

Capital adequacy and profitability: CAR (overall banking system and individual banks); and return on equity (overall banking system and individual banks). Liquidity and funding risks: liquid assets to total liabilities; liquid assets to short-term liabilities; loan-to-deposit ratio; and share of external funding in total liabilities. Asset quality: Credit to the private sector (real growth rate and share of GDP); and nonperforming loan ratios (overall banking system and individual banks).

Assessment of supervisory standards and practices based on FSAP findings. Assessment of legal and institutional framework and operational capacity for prompt corrective actions and emergency liquidity assistance.

Subscription to the SDSS or a judgment that satisfactory progress is being made toward meeting its requirements. Routine assessments (Article IV consultations) of data quality and integrity, informed by data ROSCs, where available.

\section{CInternational Monetary Fund. Not for Redistribution}




\begin{tabular}{|c|c|c|}
\hline \multicolumn{3}{|c|}{ Annex I. Table 2. Core Indicators for FCL and PLL Qualification Criteria } \\
\hline & Criterion & Indicator ${ }^{1 /}$ \\
\hline 1 & Sustainable External Position & $\begin{array}{l}\text { Requires the member's external position to have been assessed, in } \\
\text { the most recent Board document (Article IV or ESR), as "broadly } \\
\text { consistent", "moderately stronger (weaker)", "stronger", or } \\
\text { "substantially stronger" than implied by fundamentals and desirable } \\
\text { policies. }{ }^{2} \text { This assessment implies that members with "weaker" or } \\
\text { "substantially weaker external positions" would not meet the } \\
\text { criterion. The asymmetry in the assessment follows the reasoning that } \\
\text { "weaker" or "substantially weaker" external positions (e.g., high } \\
\text { current account deficit or net foreign liabilities, overvalued exchange } \\
\text { rate, etc.) constitute early warning indicators for impending BOP } \\
\text { crises. }\end{array}$ \\
\hline 2 & $\begin{array}{l}\text { Capital account position dominated by private } \\
\text { flows }\end{array}$ & $\begin{array}{l}\text { Requires public flows to account for less than half of a member's } \\
\text { direct, portfolio, and other asset and liability flows, on average in the } \\
\text { past three years. }\end{array}$ \\
\hline 3 & $\begin{array}{l}\text { Track record of steady sovereign access to capital } \\
\text { markets at favorable terms }\end{array}$ & $\begin{array}{l}\text { Requires public sector issuance or guaranteeing of external bonds or } \\
\text { disbursements of public and publicly-guaranteed external } \\
\text { commercial loans in international markets during at least three of the } \\
\text { last five years for which data are available, in a cumulative amount } \\
\text { over that period equivalent to at least } 50 \text { percent of the country's } \\
\text { Fund quota at the time of the assessment. }{ }^{4} \text { The indicator also requires } \\
\text { that the member did not, in staff's assessment, lose market access at } \\
\text { any point in the last } 12 \text { months. Following the Fund's framework for } \\
\text { loss of market access, deteriorating funding conditions and adverse } \\
\text { changes in issuance patterns (volume, maturity, and frequency of } \\
\text { issuance) that cannot be explained by funding needs would be } \\
\text { indications that the member has indeed lost market access. }{ }^{5}\end{array}$ \\
\hline 4 & $\begin{array}{l}\text { Reserve position which-notwithstanding potential } \\
\text { BoP pressures that justify Fund assistance- } \\
\text { remains relatively comfortable (precautionary } \\
\text { requests) }\end{array}$ & $\begin{array}{l}\text { Requires reserves to have been greater than } 100 \text { percent of the ARA } \\
\text { metric on average over three (the current and the two previous) } \\
\text { years, and not below } 80 \text { percent in any of these three years. By } \\
\text { including a lower-but not an upper-threshold for reserves, the } \\
\text { assessment follows the reasoning that excess reserve holdings, while } \\
\text { possibly undesirable from a systemic perspective, do not constitute a } \\
\text { vulnerability for the member. }\end{array}$ \\
\hline 5 & $\begin{array}{l}\text { Sound public finances, including a sustainable } \\
\text { public debt position determined by a rigorous and } \\
\text { systematic debt sustainability analysis }\end{array}$ & $\begin{array}{l}\text { Requires the member's public debt to be assessed as sustainable with } \\
\text { a high probability. The high probability assessment would explicitly } \\
\text { take into account risks to public finances not immediately visible in } \\
\text { current public debt projections. }\end{array}$ \\
\hline
\end{tabular}




\begin{tabular}{|c|c|}
\hline \multicolumn{2}{|c|}{ Annex I. Table 2. Core Indicators for FCL and PLL Qualification Criteria (concluded) } \\
\hline Criterion & Indicator ${ }^{1 /}$ \\
\hline $\begin{array}{l}6 \text { Low and stable inflation, in the context of a sound } \\
\text { monetary and exchange rate policy }\end{array}$ & $\begin{array}{l}\text { Requires the member to have maintained single-digit inflation over } \\
\text { the past five years. The bottom-line assessment would consider if the } \\
\text { member's performance is seen to reflect favorable external conditions } \\
\text { and there are grounds to question the ability of its policy framework } \\
\text { to maintain low inflation under normal circumstances. It would also } \\
\text { consider persistent deviations from stated inflation targets, as well as } \\
\text { sustained deflation, to the extent that it reflects deficiencies in the } \\
\text { monetary policy framework. }\end{array}$ \\
\hline $\begin{array}{l}\text { Sound financial system and the absence of solvency } \\
\text { problems that may threaten systemic stability }\end{array}$ & $\begin{array}{l}\text { Requires the average capital adequacy ratio for the banking sector to } \\
\text { be above regulatory thresholds, and that the most recent Article IV } \\
\text { did not highlight significant solvency risks or recapitalization needs. } \\
\text { The bottom-line assessment would consider other financial } \\
\text { soundness indicators, as well as any relevant stress tests conducted } \\
\text { by staff, to provide a forward-looking perspective. It would also } \\
\text { reflect potential problems in large and systemic banks that may be } \\
\text { masked by system-wide averages. }\end{array}$ \\
\hline $8 \quad$ Effective financial sector supervision & $\begin{array}{l}\text { Requires that the most recent FSAP or Article IV report did not raise } \\
\text { substantial concerns regarding the supervisory framework. The } \\
\text { bottom-line assessment would consider any significant changes in } \\
\text { conditions since the latest FSAP. }\end{array}$ \\
\hline $9 \quad$ Data transparency and integrity & $\begin{array}{l}\text { Requires that the member is an SDDS subscriber or has made } \\
\text { satisfactory progress toward meeting the SDDS requirements. }\end{array}$ \\
\hline \multicolumn{2}{|c|}{$\begin{array}{l}\text { 1/ Please note that the assessment of policy track record will be anchored in the same set of core indicators based on an assessment of the } \\
\text { qualification criteria in each of the five most recent years. Also, while judgment is important for all nine criteria, it is particularly important } \\
\text { for criteria } 6,7 \text {, and } 8 \text {. }\end{array}$} \\
\hline \multicolumn{2}{|c|}{$\begin{array}{l}\text { 2/ The assessment of a member's external position as per the mandatory external sector assessment in surveillance takes into account the } \\
\text { following five key areas: current account (CA), real exchange rate, foreign exchange intervention and reserves, foreign assets and liabilities, } \\
\text { and capital and financial account. The bottom line assessment of a member's external position falls into one of the following seven } \\
\text { categories, guided by the corresponding indicative ranges for the staff-assessed CA gaps (in percent of GDP) with considerations of all } \\
\text { other areas: (i) substantially stronger (CA gaps more than } 4 \text { percent); (ii) stronger (CA gaps between } 2 \text { and } 4 \text { percent); (iii) moderately } \\
\text { stronger (CA gaps between } 1 \text { and } 2 \text { percent); (iv) broadly consistent (CA gaps between }-1 \text { and } 1 \text { percent); (v) moderately weaker (CA gaps } \\
\text { between - } 2 \text { and - } 1 \text { percent); (vi) weaker (CA gaps between - } 4 \text { and - } 2 \text { percent); and (vii) substantially weaker (CA gaps less than - } 4 \text { percent). }\end{array}$} \\
\hline \multicolumn{2}{|c|}{$\begin{array}{l}\text { 3/ Public flows are flows to and from the domestic public sector, and are defined as the sum of the absolute values of reserve assets flows, } \\
\text { and general government and central bank portfolio and other debt liability flows. In the absence of data for a large sample of countries, } \\
\text { other official asset and liability flows of the public sector are assumed to be zero. }\end{array}$} \\
\hline \multicolumn{2}{|c|}{$\begin{array}{l}{ }^{4 /} \text { This indicator assessment broadly follows the market access criterion for (graduation from) PRGT eligibility. The bottom-line assessment } \\
\text { will consider if there is convincing evidence that the sovereign could have tapped international markets on a durable and substantial basis, } \\
\text { even though the scale or duration of actual public-sector borrowing fell short of the specified thresholds. This would be a case-specific } \\
\text { assessment, informed by factors such as the volume and terms of recent actual borrowing in international markets and the sovereign credit } \\
\text { rating. }\end{array}$} \\
\hline \multicolumn{2}{|c|}{$\begin{array}{l}\text { 5/ A methodology for making this assessment was articulated in "The Fund's Lending Framework and Sovereign Debt-Further } \\
\text { Considerations", IMF Policy Paper, April } 2015 .\end{array}$} \\
\hline \multicolumn{2}{|c|}{$\begin{array}{l}\text { 6/ See Annex III for an empirical justification of the } 80 \text { percent threshold. The overall assessment could consider other reserve metrics if the } \\
\text { ARA metric is deemed inadequate for judging the member's reserve position. This assessment should generally be reflected in recent } \\
\text { Article IV reports. }\end{array}$} \\
\hline
\end{tabular}




\title{
Annex II. Determining Access on a Precautionary Basis
}

\author{
1. This annex provides a framework for use by staff when considering access in a \\ precautionary setting, for example in the context of FCL and PLL arrangements. It is additional \\ to the guidance provided in Annex II, GRA Lending Toolkit and Conditionality-Reform Proposals, \\ and draws upon the approach used for the FCLs agreed for Mexico, Poland, and Colombia.
}

2. Aim: To ensure Executive Board papers include a rigorous analysis of the determination of access levels based on a consistent framework but allowing for country-specific flexibility; and recognizing the high degree of judgment involved in estimating a potential financing gap. The underlying assumptions on which the level of access is based should be clearly spelled out in Board reports and staff should show that access looks reasonable when compared with a range of metrics and indicators.

\section{A. Key Criteria for Access}

3. The key criteria that govern access decisions in individual country cases are: (i) the member's actual or potential need for Fund resources, taking into account other sources of financing and the desirability of maintaining a reasonable level of reserves (Fund policy establishes that in no circumstances can access be greater than this need); (ii) the member's capacity to repay the Fund (including the strength of the member's adjustment program); and (iii) the member's outstanding Fund credit and its track record of using Fund resources. These criteria are broad and require substantial judgment, even more so when access is requested on a precautionary basis.

\section{B. Framework for Determining Access in a Precautionary Setting}

4. When access is requested on a precautionary basis, staff should construct a plausible adverse scenario to help determine an estimated potential financing gap and the appropriate level of access. Additional factors - beyond the potential financing gap in the adverse scenariocould be given weight when forming a judgment about the appropriate level of access but these would need to be carefully justified. In particular, to enhance transparency and evenhandedness of access decisions across arrangements, staff should (i) place attention in presenting the link between access and the size of actual or potential BoP needs in individual cases; (ii) allow comparability in the choice of the adverse shocks underpinning the access scenarios, while also taking into account country-specific factors; and (iii) cross-check programmed reserves against standard adequacy metrics, as discussed below.

5. The construction of the adverse scenario should be informed by: (i) downside global assumptions in line with the latest WEO downside scenario, GFSR or Global Risk Assessment Matrix (GRAM) (with a description of the potential shock and how likely it is); (ii) developments in an index of external economic stress (described below and further in Annex III); (iii) evidence from past or current crises (described also below and further in Annex IV); and (iv) country specific factors (and likelihood based on past experience). The adverse scenario should also take into account whether 
there is a case for an orderly exchange rate adjustment and whether reserve coverage (on a number of metrics, including the Fund's Assessing Reserve Adequacy (ARA) metric) suggests that the reserve level should be maintained, raised, or lowered. For example, if a country is hit by a permanent shock that affects the equilibrium exchange rate, the role of Fund financing/insurance may be to help the country to move to a new equilibrium in an orderly manner rather than to preserve the previous real exchange rate. Even if the shock is assumed to be temporary, the description of the adverse scenario should make clear the assumed direction of change in the exchange rate and the implied impact on financing needs. With respect to reserve coverage, discussions of the access level during the internal review process could consider alternative reserve drawdown scenarios-such as access levels under a lower bound of reserves for the given country (see below for considerations regarding reserve drawdowns), with consideration also to the pace of reserve drawdown to avoid adverse market reactions. A decision to maintain reserve levels significantly above the lower bound in the adverse scenario should be clearly justified in the staff report. In determining the scale of access, teams also need to ensure that the balance of payments tables demonstrate the potential need. Annex Table 1 provides a guide to the shocks that could be used to construct this scenario (but such examples should be considered as defining the minimum set of information required on the underlying assumptions and factors determining the scale of access).

6. Global assumptions. The adverse scenario should draw its global assumptions from the most relevant downside risks to the external environment as identified by the latest WEO downside scenario, GFSR, or G-RAM. Staff reports should indicate the scenario used (and the probability attached to the scenario). The chosen scenario should also be informed by the downside scenario in the external economic stress index. While these two scenarios do not need to be identical, the source of the shock and direction of the risks should be consistent. Where the WEO and GFSR are clearly out of date, staff should briefly justify the use of different global shocks.

- The WEO and GRAM provide a useful reference for quantitative estimates of global economic and financial shocks, which could inform the effects on the country's export demand, terms of trade, and remittances.

- The GFSR should be the main source for key global and regional assumptions on financing conditions, including surveys of market analysts' expectations, under the baseline and an adverse scenario.

7. Index of External Economic Stress. The adverse scenario should also be informed by how these global assumptions impact the measured level of external risk in a particular country. To help assess how external risks evolve for a particular country, following consultation with country authorities, country teams should develop an index of external economic stress, the mechanics of which are set out in Annex III. This index is designed to provide an indication of the evolution of the external environment as it relates to the country in question.

8. The index should be used to help guide access discussions. When the index indicates more elevated risks than previously identified, the adverse scenarios would normally be expected to include assumptions that are more extreme; similarly, when the index shows lower stress, the 
assumed shocks should be correspondingly smaller. As these risks decline over time, access would be expected to decline, which would be consistent with a member progressively exiting from arrangements under the FCL. Nevertheless, as with other aspects of the exercise, the discussion will be subject to a high degree of uncertainty, and the role of judgment will remain paramount.

9. Evidence from previous and current crisis cases, including as described in economic literature, could additionally inform the impact of global and country specific shocks on the balance of payments. In particular, past crisis episodes could provide a useful reference for the size of the expected shock on different components of the capital account, including FDI, rollover rates, and resident and nonresident deposit outflows (see suggested approach in Annex IV, which has now been adopted by all FCL and PLL users).

10. Country-specific factors. Although global assumptions and past crises episodes could provide valuable information on the possible behavior of different elements of the BoP at times of distress - and ensure comparability of scenarios across country requests-country-specific characteristics will usually be a critical component of the adverse scenario, to ensure that it is plausible. In particular, desks may want to focus on the country-specific structure and resulting volatility of capital flows, as well as specific items (e.g., derivatives, intra-group lending, private foreign assets holdings), that could either exacerbate or mitigate potential BoP pressures. When using country-specific factors, staff will need to defend the scale of the specific shock (e.g., the probability that this type of shock will occur based on past experience and current developments) and provide full explanations in the relevant Board documents. Moreover, additional access cushions-beyond those considered under the adverse scenario-should be carefully justified. Nevertheless, under the Fund's Transparency Policy, market-sensitive information on access determination can be deleted from staff reports before publication, where warranted by circumstances.

11. Additional considerations and reserve adequacy. An assessment of reserve adequacy and how this would be affected if the adverse scenario materializes is also necessary (see also Assessing Reserve Adequacy, Assessing Reserve Adequacy_Further Considerations, and Assessing Reserve Adequacy-Specific Proposals). Staff should compare reserve levels according to different metrics relevant for given country-specific vulnerabilities and relevant for the exchange rate regime (e.g., the Fund's ARA metric as well as other standard metrics). With reserve drawdown a key element in determining access levels, limited reserve drawdown should be clearly justified and reserve adequacy ratios well into the adequacy range in the adverse scenario should be generally avoided. Specifically, it would normally be expected that assumed levels of gross reserves are allowed to fall below 100 percent of the ARA in the adverse scenario (since this is an extreme stress event). In this respect, the 2014 Review of the FCL, the PLL, and the RFI included discussion of a lower threshold level of 80 percent of the Fund's ARA metric. ${ }^{1}$ However, when considering the appropriate reserve drawdown,

\footnotetext{
1 Using a large sample of EMs over a 22-year period, the reserve threshold was derived so as to minimize ExchangeMarket-Pressure crisis prediction errors. The "optimal" threshold minimizes the sum of type I and type II crisis
}

(continued) 
the pace of the drawdown should also be considered to avoid adverse market reactions. Overall, for countries for which reserve levels are above adequate, the adverse scenario should include the use of international reserves to cover part of the financing gap, implying that not all the potential financing need is met through Fund resources. Where it is clear that reserve levels need to rise over the course of the FCL arrangement to maintain reserve adequacy, staff may want to build in an increase in reserve levels in the baseline projection. In tandem with assessing the level of reserves, staff should also consider whether an orderly exchange rate adjustment might be necessary if the adverse scenario unfolds (since it may not be appropriate for Fund financing to support the previous level of the real exchange rate in the face of a permanent shock). As noted above, assumptions regarding the exchange rate and any impact on financing needs should be clearly spelled out in terms of the direction and implied impact on financing needs.

12. Access levels should always be presented based on the potential BoP need, irrespective of the specific use of Fund resources by the member (budgetary support, reserve build up, bank restructuring costs). ${ }^{2}$ Access to Fund resources can be granted to finance potential budgetary needs as long as the deficit in the public sector saving-investment (S-I) balance is mirrored by a BoP need (see Box 3 in 2009 Review of Recent Crisis Programs). For example, a BoP need could be deemed to arise in the context of an economic contraction if appropriate stimulative policies (including fiscal) would lead to a worsening of the current account-i.e., the deterioration of the public sector S-I balance is not offset by an improvement in the private sector S-I balance (crowding out). In the absence of external financing, the use of Fund resources to prevent a maladjustment of the balance of payments (excessive current account contraction) would be warranted. ${ }^{3}$ Operationally, proposed access levels should be commensurate with the projected BoP need shown in staff reports.

\section{Estimates of precautionary BoP needs and thus the corresponding access level can be} appropriately based over a rolling 12-month window, even for longer-duration arrangements, in line with evidence from past crisis cases (see 2009 Review of Recent Crisis Programs paper).

14. Finally, staff should check that the level of access is appropriate, not just with respect to financing gap estimates but also with respect to a wider range of metrics and indicators related to capacity to repay and quota (for this purpose, the policy note, and staff report should include a comparison of high access cases indicators table).

prediction/misclassification errors to avoid missing crises (threshold too high) and predicting false crises (threshold too low). Hence, with an 80 percent threshold separating crisis from non-crisis signals, countries may be able to draw down reserves to that limit in severe stress events without igniting crisis risks.

${ }^{2}$ A purchase can only be made in the GRA by a member if it represents that it has to make the purchase to meet a BoP need-i.e., "because of its balance of payments or its reserve position or developments in its reserves." (Article I, Section $3(b))$.

${ }^{3}$ From the Articles of Agreement, Article I stipulates that one of the purposes of the Fund is "To give confidence to members by making the general resources of the Fund temporarily available to them under adequate safeguards, thus providing them with opportunity to correct maladjustments in their balance of payments without resorting to measures destructive of national or international prosperity." 


\begin{tabular}{|c|c|c|c|}
\hline \multicolumn{4}{|c|}{ Annex II. Table 1. Illustrative BoP Shocks in Adverse Scenarios } \\
\hline $\begin{array}{l}\text { External Financing } \\
\text { Requirements and Sources: } \\
\text { Potential Shocks }\end{array}$ & $\begin{array}{c}\text { Downside Risks to the Current } \\
\text { External Environment } \\
\text { (WEO, GFSR, GRAM, VE, and EWE) }\end{array}$ & $\begin{array}{l}\text { Evidence from Previous and } \\
\text { Current Crisis Cases }\end{array}$ & $\begin{array}{l}\text { Country Specific Risks and/or } \\
\text { Compensating Factors }\end{array}$ \\
\hline $\begin{array}{l}\text { A. Current Account } \\
\text { Foreign demand } \\
\text { Commodity prices } \\
\text { Remittances }\end{array}$ & $\begin{array}{l}\text { WEO alternative scenario (global } \\
\text { growth and commodity price } \\
\text { decline with respect to baseline) } \\
\text { G-RAM }\end{array}$ & $\begin{array}{l}\text { Impact of advanced economies' } \\
\text { downturn on emerging markets }\end{array}$ & $\begin{array}{l}\text { Exports/Imports composition and elasticities } \\
\text { Current account norm and debt-stabilizing leve }\end{array}$ \\
\hline B. FDI & $\begin{array}{l}\text { Early Warning Exercise (EWE) } \\
\text { /GFSR/Vulnerabilities Exercise (VE) } \\
\text { GRAM }\end{array}$ & $\begin{array}{l}\text { FDI decline in representative } \\
\text { cases } \\
\text { Historical volatility vis-à-vis other } \\
\text { capital flows }\end{array}$ & $\begin{array}{l}\text { Foreign bank takeovers } \\
\text { Investments in nontradable sector } \\
\text { Greenfield investments } \\
\text { Retained earnings }\end{array}$ \\
\hline $\begin{array}{l}\text { C. Equities and debt } \\
\text { securities }\end{array}$ & VE/GRAM & $\begin{array}{l}\text { Nonresident holdings of and } \\
\text { outflows from domestic equity } \\
\text { and bonds }\end{array}$ & $\begin{array}{l}\text { Need to account for valuation effects and } \\
\text { secondary market liquidity }\end{array}$ \\
\hline $\begin{array}{l}\text { D. Debt Rollover } \\
\text { MLT/ST } \\
\text { Sovereign/bank/ } \\
\text { nonbank } \\
\text { Official/private }\end{array}$ & $\begin{array}{l}\text { MCM survey of market analysts' } \\
\text { expectations as per VE } \\
\text { GRAM }\end{array}$ & Rollover rates & $\begin{array}{l}\text { Debt composition } \\
\text { Trade credits } \\
\text { Intra-group lending } \\
\text { Private Sector Involvement }\end{array}$ \\
\hline $\begin{array}{l}\text { E. Other Investment } \\
\text { Currency and } \\
\text { deposits } \\
\text { Secondary market } \\
\text { Derivatives position } \\
\text { Other }\end{array}$ & GFSR/VE/GRAM & $\begin{array}{l}\text { Stock and flows of nonresident } \\
\text { deposits } \\
\text { Resident deposits outflows }\end{array}$ & $\begin{array}{l}\text { Nonresident holdings of domestic debt } \\
\text { Hedged derivatives position in tradable sector } \\
\text { Degree of dollarization }\end{array}$ \\
\hline $\begin{array}{l}\text { F. Gross International } \\
\text { Reserves and Private } \\
\text { Foreign Assets }\end{array}$ & $\begin{array}{l}\text { Greenspan-Guidotti rule } \\
\text { Jeanne-Ranciere Reserve rule } \\
\text { Other indicators mentioned in } \\
\text { Annex I }\end{array}$ & Evidence from programs & $\begin{array}{l}\text { Metrics selected on the basis of relevant } \\
\text { vulnerabilities } \\
\text { Availability of liquid foreign assets by private } \\
\text { sector }\end{array}$ \\
\hline
\end{tabular}




\section{Annex III. Index of External Economic Stress}

\section{The assessment of external risks is critical to both the justification of access and the prospects for exit from use under the FCL or PLL. In this regard, during the $2014 \mathrm{FCL} / \mathrm{PLL} / \mathrm{RFI}$} Review most Directors considered that an indicator of external stress would be a useful innovation to strengthen the discussion of a country's external risks in staff reports for requests for, and reviews under, FCL and PLL arrangements. The index would be an indicator of the evolution of the external environment as it pertains to the particular member, and would aim to help inform discussions of access and exit prospects. ${ }^{1}$ In this annex, a general and flexible methodology is outlined to guide staff in constructing such indices tailored to a member's specific economic situation. The development of the index would be undertaken by individual country teams, after discussion with the authorities, as part of the preparation of a staff report on an FCL or PLL arrangement. The methodology serves as a basic framework to be used in relevant staff reports for members using these arrangements, but is flexible to permit tailored applications to different country cases and refinements by mission teams. ${ }^{2}$ To allow the Board to assess relative risks over time, the type of risks, variables, and size of weights on each of these variables, once decided, would be expected to remain set within and across successor arrangements, absent a compelling economic reason which should be presented clearly in the report.

2. Any index will, broadly, require three main choices: (i) the selection of the key external risks facing the country; (ii) the selection of proxy variables capturing these risks; and (iii) the choice of the weights to apply to each of these variables. The index will be a weighted sum of standardized deviations of the external proxy variables from their means. Country teams should discuss these key modeling choices with the relevant country authorities, although country teams will ultimately be responsible for making these decisions. The choice of index should be justified in a thorough manner, while striking the right balance between flexibility that allows for country-specific considerations and standardization that ensures evenhandedness and consistency over time.

- Risks. The principal external risks specific to a country are typically identified by country teams in Article IV consultation staff reports, following discussion with country authorities, including drawing on risks identified in the Global Risk Assessment Matrix (G-RAM). Key vulnerabilities could include, for example, portfolio and cross-border bank flows, exports to key trading partners, workers' remittances from a single country or region, and commodity prices changes for commodity exporters.

- Variables. Each risk would be represented by proxy variable(s) that capture(s) the external factors relevant to the risk. For example, if exports to the euro area are a key risk, euro area growth could be the external proxy variable. Risks associated with portfolio debt liability risks

\footnotetext{
1 This index is not intended to help inform qualification decisions, which are subject to the qualification framework.

2 However, any use of the index would be based on broadly applicable principles that ensure uniformity of treatment among Fund members so that similarly situated members will be treated similarly in the use of Fund resources under the FCL and PLL.
} 
could be linked to U.S. treasury yields, and equity portfolio investment could be related to volatility in emerging markets.

- Weights. Different methods can be used to calculate the weights for the selected variables, depending on data availability and relevance of different techniques. As the default, simple statistics could be used to derive the weights (data-based). However, where appropriate and feasible, country teams could explore more advanced econometric methods (model-based), as long as they lead to economically meaningful weights.

- Data-based weights. Under this method, weights would be determined by the economic size of the respective balance of payments vulnerability relative to the overall size of the economy. For instance, if the vulnerability is exports to a particular market, the long-term average size of those exports would be calculated as a share of the country's output.

- Model-based weights. As an example of this method, vector autoregressions could be used to estimate the importance of each of the risks on observed balance of payment pressures (see Annex Box 1 for an illustration of the use of model-based weights).

3. To demonstrate the possible estimation of external economic stress indices, this note includes illustrative indices taken from the 2014 FCL, PLL, and RFI Review for Mexico, Colombia, and Poland (Annex Table 1 and Annex Figure 1). These indices bring together selected sources of external risk facing these countries. They measure whether a country's external environment is better or worse than normal since each index uses differences of the proxy variables from long-run means. ${ }^{3}$ Annex Table 1 reports the key risks, proxy variables and weights identified through the two approaches proposed above. While the individual weights differ in certain cases, both weighting methods produce broadly similar overall stress indices (Annex Figure 1).

\section{The assessment of external risks needs to both capture recent changes in the external} environment and be forward looking. In this context, a downside risk scenario should be modeled by country teams with relevant input from country authorities, drawing where appropriate on the most recent flagship reports (i.e., WEO downside scenario, GFSR, spillover reports) or G-RAM. While the impact of a given shock would likely differ across countries, reflecting different exposures and hence different ESI weights, the underlying shock scenario would be expected to be similar across countries with arrangements falling close in time. Should different assumptions (e.g., different shock size) be warranted, this could be clarified by specifying the context surrounding the given shock. The selected scenario should be fully justified and explained in the related staff reports. The chosen downside risk scenario should also inform the downside scenario chosen in the adverse financing needs scenario. While these two scenarios do not need to be identical, the source of the shock and direction of the risks should be consistent. Annex Figure 1 presents, as an example, illustrative downside risks for the three FCL users mentioned above.

\footnotetext{
3 To make the deviations from averages comparable across proxy variables and therefore additive in a weighted average, the index also divides the differences by the long-run standard deviation of the respective proxy variables.
} 
Annex III. Box 1. An IIlustrative Estimation of External Economic Stress Index Weights

The empirical method for calculating the stress index weights could employ structural Bayesian vector autoregression (BVAR) estimation. This technique detects the actual historical relation of a country's balance of payments pressures to external proxy variables, controlling for variation in the domestic economy.

The BVAR approach uses the same external proxy variables that correspond to vulnerabilities identified by staff as those employed in the data-based weights described in the main text. BVAR is a technique that relates a vector of macroeconomic variables to its past realizations. In this application, that vector is comprised of the external proxy variables (as described in Annex Table 1), domestic control variables (in this case GDP growth and short-term money market interest rates) and a variable-the quarterly average exchange market pressure (EMP) index-representing the balance of payments pressures facing the country. The external variables used for the three current FCL countries are as follows:

- $\quad$ Poland. Seasonally-adjusted euro area quarter-on-quarter real output growth, the quarterly change in the U.S. Treasury 10-year yield, the logarithm of the quarterly average value of the Euro Stoxx Banks index, and the quarterly average value of the VXEEM index. ${ }^{1}$

- Mexico and Colombia. Seasonally-adjusted U.S. quarter-on-quarter real output growth, change in quarterly average oil price, the quarterly change in the U.S. Treasury 10-year yield, and the quarterly average value of the VXEEM index.

The structural BVAR employs the Cholesky scheme to identify the structural impulses driving external developments in the model. This approach requires an ordering of variables in the BVAR vector such that each variable only impacts contemporaneously the variables that follow it in the ordering. Specifically, the ordering of external variables is the same as outlined in the bullets above and such that external trading partner growth is the most exogenous, followed by commodity prices and foreign interest rates. These variables are followed by the domestic variables, i.e. output growth, interest rate, and EMP. The model applies a shrinking parameter to the latter group such that domestic variables do not influence the external proxy variables. The models are estimated using data from 1995 (or the earliest available) with 2 lags. BVAR uses priors regarding means and standard deviations on the constant term as well as the first order autocorrelation, ${ }^{2}$ which improves the efficiency of the estimation. Results are qualitatively robust to alternate ordering of external variables and lag length.

One of the outputs of the BVAR is a set of impulse response functions. These depict the response in each variable's values over time to a one standard deviation shock to one of the variables. Each of these functions was surveyed in the three models for the FCL countries to ensure that the model produced sensible results for all of the vector components.

The set of impulse responses of EMP to the external proxy variables is then used to calculate the external economic stress index weights. In particular, the absolute cumulative response over a year of exchange market pressure to each of the external risk proxies is used to weight the relative importance of each risk. In other words, the larger the impact on EMP (and therefore BoP pressures) of a shock in a particular proxy variable, the larger its weight in the index.

\footnotetext{
1Since VXEEM values are only available starting in 2011, prior to that VIX values are used instead, with an additional spread calculated as the average spread between VIX and VXEEM in 2011-2013.

${ }^{2}$ The priors are based on historical means, variances and autocorrelations over the estimation period.
} 


\section{Annex III. Table 1. External Economic Stress Index Components}

\section{Mexico}

External risk

External proxy variable

Data-based weights

Model-based weight

Exports to the US

FDI from the US

US growth

0.43

0.23

Remittances from the US

Oil exports

\section{Change in oil price}

0.06

0.32

Equity portfolio investment stock

Emerging market implied volatility (VXEEM)

$-0.24$

$-0.30$

Debt portfolio investment stock

Change in US Treasury 10 year yield

$-0.27$

\section{Poland}

External risk

FDI from the Eurozone

Stock of cross country bank exposures

Equity portfolio investment stock

Debt portfolio investment stock
Exports to the Eurozone
External proxy variable

Eurozone growth

European bank equity price (Euro Stoxx Banks)

Emerging market implied volatility (VXEEM)

Change in US Treasury 10 year yield
Data-based weights

Model-based weigh

\section{Colombia}

External risk

External proxy variable Data-based weights

Model-based weigh

Oil exports

Coal exports

- Change in oil price

0.32

0.03

FDI into the oil industry

Exports to the US

US growth

0.24

0.25

Equity portfolio investment stock

Debt portfolio investment stock

Emerging market implied volatility (VXEEM)

Change in US Treasury 10 year yield

$-0.04$

$-0.44$

$-0.28$ 


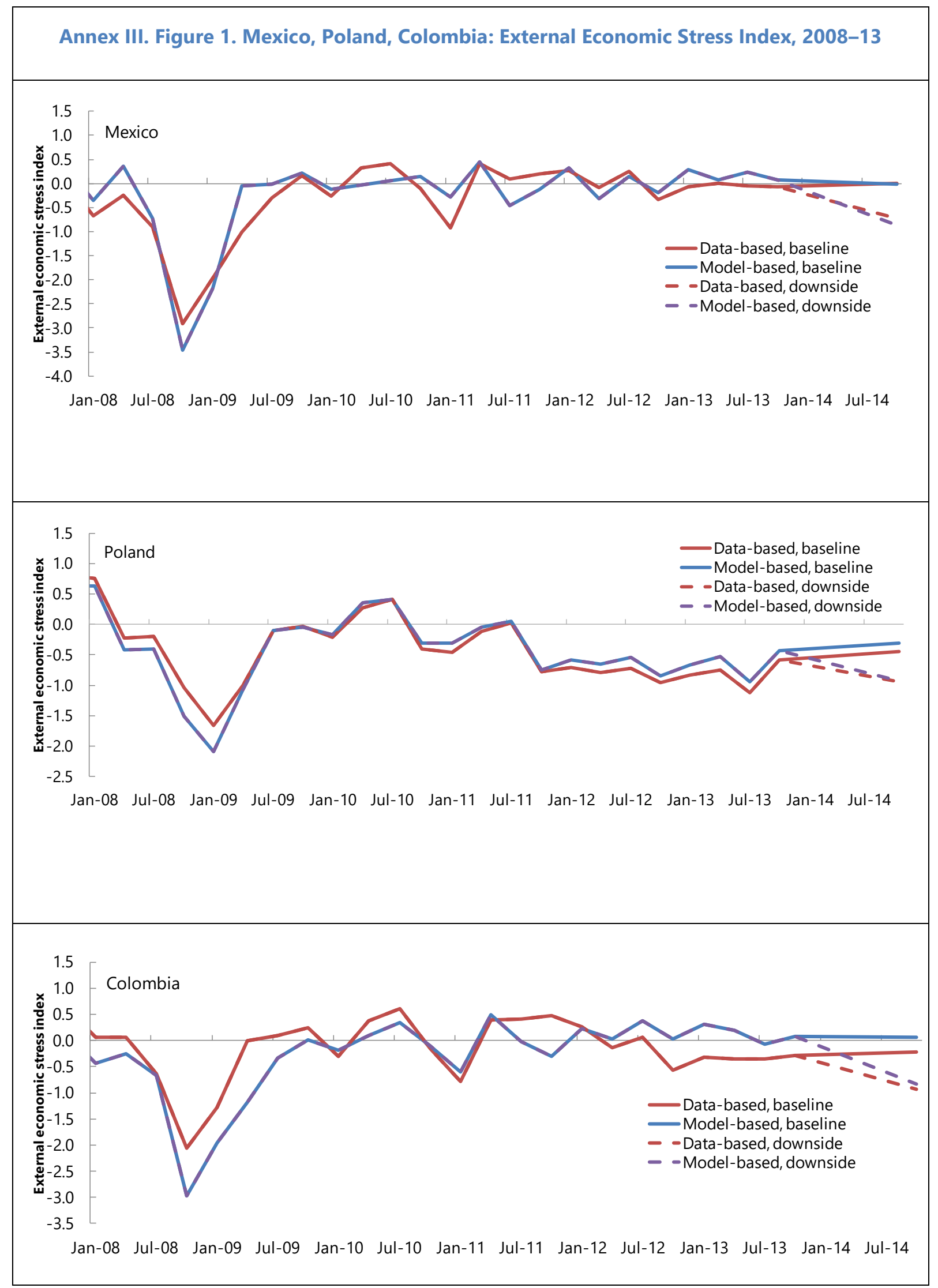




\section{Annex IV. A Framework for Comparing Access Assumptions}

1. This annex outlines a framework for comparing access assumptions across members availing themselves of the FCL or the PLL. The framework was developed in the context of the 2011 Review and has since become standard practice for access requests. The framework involves, first, identifying past events where emerging markets (EMs) have been hit by large exogenous (advanced market (AM)-led) shocks. The second step involves gathering information across EMs on key access determinants-both on the current and financial account-so that access assumptions can be compared with past behavior of key variables during shock episodes.

2. The first step involves identifying exogenous shock periods. Specifically, this involves identifying the impact on EMs stemming from a decline in domestic demand and elevated financial stress in their AM trading partners. Over the past 30 years, annual AM real domestic demand compression bridged the one standard deviation threshold in the years 1991, 2001, and 2009. Excessive AM financial stress also coincided with these events. These periods were followed by economic stresses across a number of EMs and are, as such, categorized as crisis events.

\section{The second step involves measuring moves in key external variables across EMs during these identified crisis periods.}

- Country sample. $49 \mathrm{EMs}$ are selected that are medium sized, have market access, and attract private inflows through FDI, portfolio flows, and loans. This broadly coincides with the sample of countries chosen for the Fund's Vulnerability Exercise for Emerging Markets (VEE).

- Variables. Eight separate external variables are used in the analysis, focusing on those variables in the current and financial accounts that form the basis of downside risk assumptions in past FCL access decisions. These variables comprise exports, FDI, commodity prices excluding fuel, fuel prices, and short- and MLT public and private rollover rates. (Other variables could also be added over time if needed, e.g., deposit outflows.)

- Density distributions. This step involves identifying density distributions for the behavior of external variables during past exogenous stress episodes for EMs. For each variable, values for countries $i: 1, \ldots, l$ in the event years are stacked in a vector denoted with $x$. These vectors are used to estimate univariate kernel densities. Kernel density estimators approximate the density $f(x)$ from observations on $x$. The data are divided into non-overlapping intervals, and counts are made of the number of data points within each interval so that $\mathrm{FCL}$ arrangement assumptions can be presented on these distributions with greater precision. Kernel distributions provide comparable benchmarks to calibrate the assumptions used in past $\mathrm{FCL}$ arrangements for key external variables, which in turn helped determine access levels.

- Time period. For FDI and exports, averages spanning the three years prior to the crisis year are used as a baseline. The crisis year deviations from these baselines are then used as the shock scenario. For private and public rollover rates, episode year values are used to estimate densities. Finally, for commodity and fuel prices, time series values for the 1991-2011 period 
are pooled to estimate the densities. FCL and PLL cases are placed on these densities based on the shock scenarios that are described in country case studies. ${ }^{1}$

4. To compare the implicit assumptions on tail risks across current and past FCL cases, the implicit assumptions from FCL-PLL cases are placed in the empirical distributions of key EM access parameters (see Annex Figure 1). Using this framework, it can be seen that the severity of assumed shocks fell under the second $\mathrm{FCL}$ arrangements, before increasing as global conditions worsened. Another interesting finding is varying degrees of severity of various shocks across BoP category in earlier FCL requests but which became less extreme in later requests after the implementation of this framework. It is expected that these empirical distributions are used to underpin assumptions in all future access scenarios.

5. As external risks subside, it is also expected that country teams will use less severe assumptions in their access scenarios. That is, assumptions will move closer to the center of the distribution.

6. Finally, the $\mathbf{2 0 1 4}$ review found that assumptions are increasingly conservative and severe when the assumptions are compared against distributions for the second year of a crisis, where typically the severity of the situation declines (see second part of Annex Figure 1). Country teams when requesting a two-year arrangement should thus consider using less severe assumptions in the second-year of the scenario and anchoring those assumptions in a separate empirical distribution specifically for the second year of the crisis.

\footnotetext{
${ }^{1}$ See The Review of the Flexible Credit Line, The Precautionary and Liquidity Line, and the Rapid Financing Instrument-Supplementary Information.
} 
Annex IV. Figure 1. Empirical Adverse Shock Distribution-in Crisis Year ${ }^{1 /}$
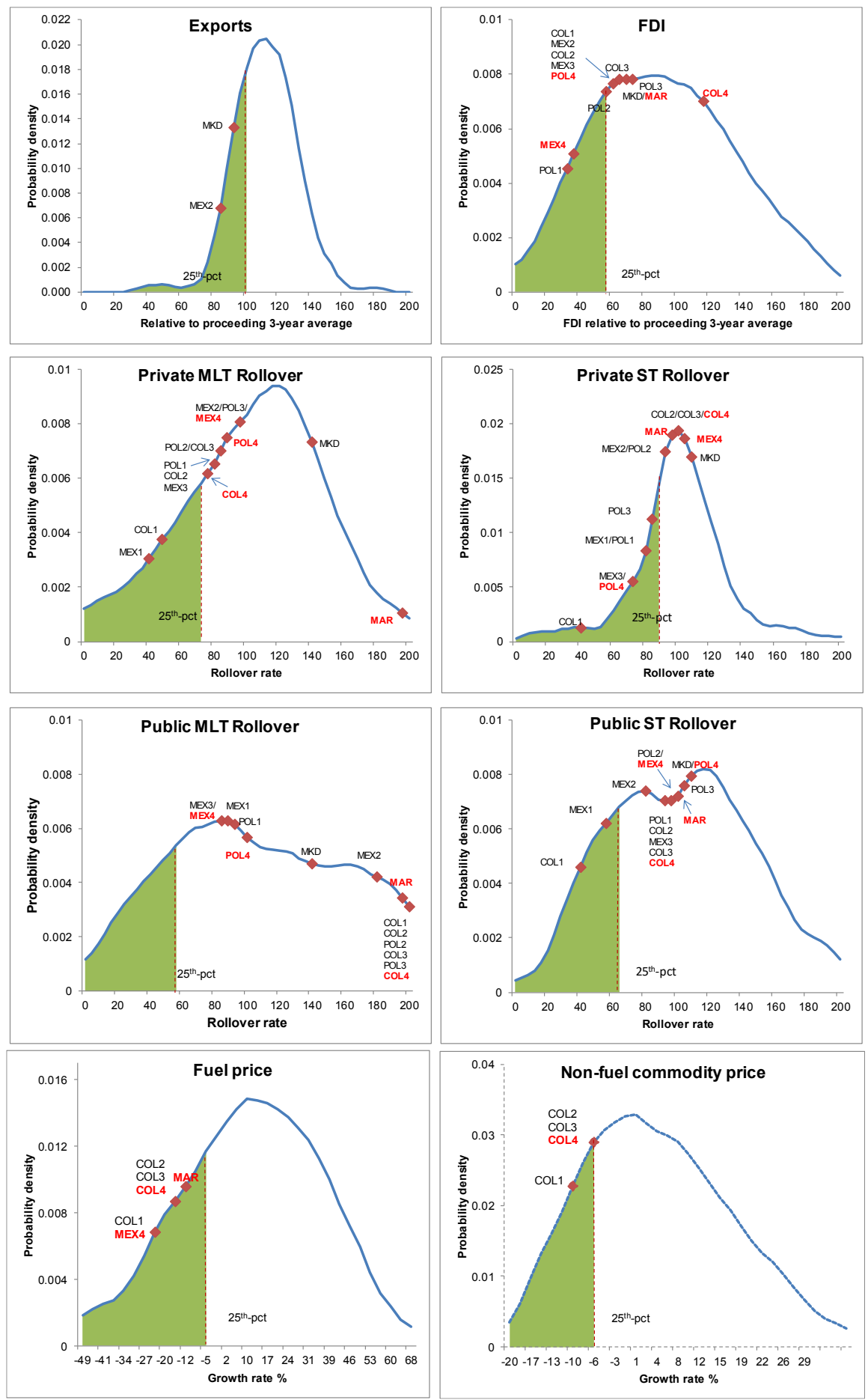

1/ In the empirical distributions, "shocks" are defined as countries' actual experiences during the crisis year (for all four types of debt rollover rates), or countries' experiences during the crisis year relative to proceeding 3-year average (for exports and FDI). This definition can be different from that in the FCL/PLL staff reports, which often define shocks as deviations in the adverse scenario from the baseline projection. In placing the shock assumptions underpinning the $\mathrm{FCL} / \mathrm{PLL}$ arrangements on the empirical distributions, staff recalculates the FCL/PLL shock assumptions so that the definition of shocks is in line with that underlying the empirical distributions. 
Annex IV. Figure 1. Empirical Adverse Shock Distribution-One Year After the Crisis (concluded)
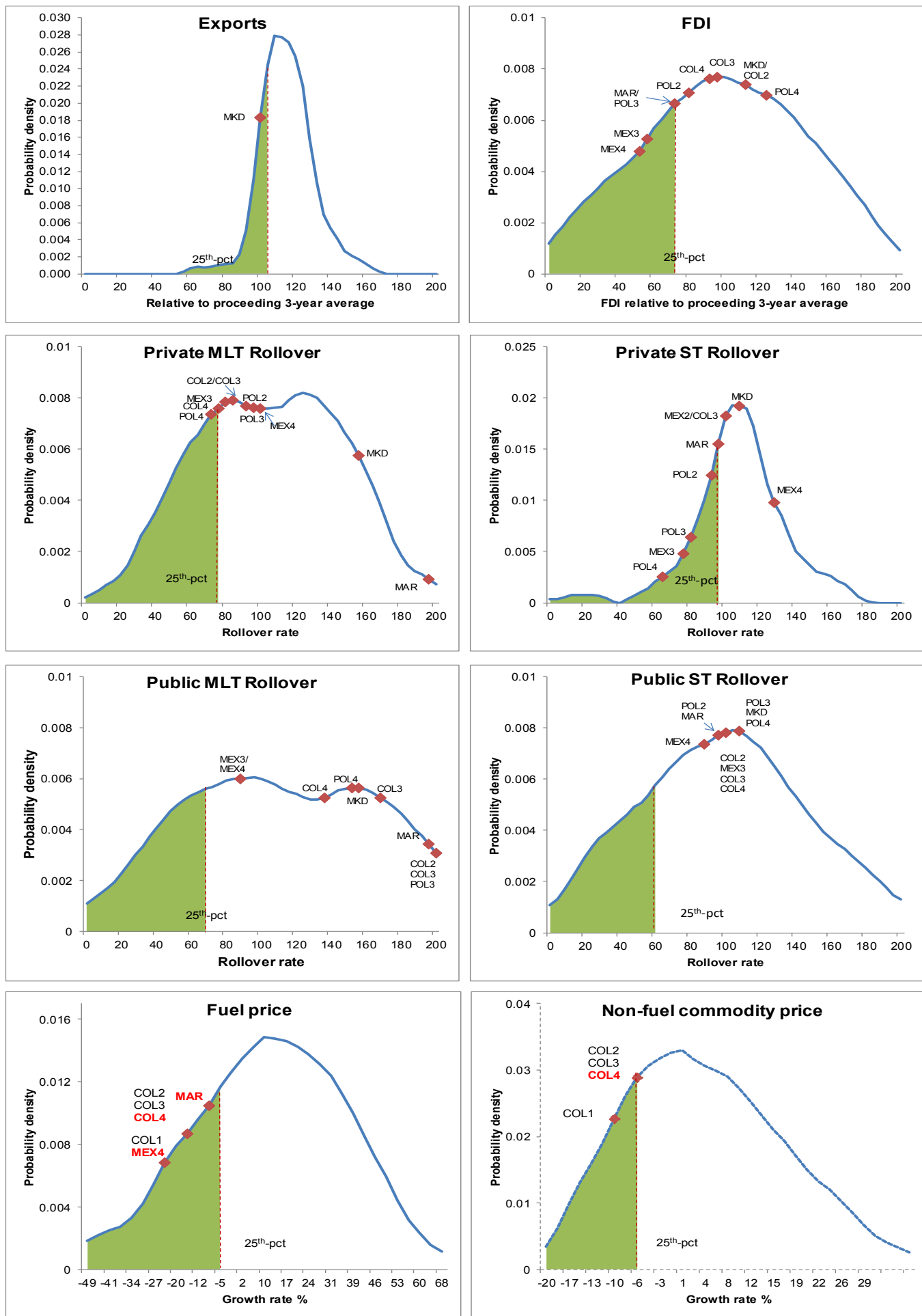

Sources: WEO, IFS, and IMF staff calculations.

Note: Rollover rates are computed as the amount of new borrowing in year $t$ divided by the amortization falling due in that year. 


\section{Annex V. Staff Documents for the Executive Board on the Use of FCL Resources}

\section{A. Concise Staff Note for Informal Board Meeting}

1. The staff note should focus on qualification and access issues and, accordingly, can be significantly more succinct than the staff report for the formal board meeting. The note should include:

- Qualification. An assessment of whether the member (a) has very strong economic fundamentals and institutional policy frameworks; (b) is implementing-and has a sustained track record of implementing-very strong policies; and (c) remains committed to maintaining such policies in the future, all of which give confidence that the member will respond appropriately to the balance of payments difficulties that it is encountering or could encounter. A statement on whether the most recent (2-3 years) Article IV consultations included very positive assessments of the member's policies. A preliminary assessment of the qualification criteria in Annex I, including, where necessary, a reference to aspects of the criteria that require more information in order to be assessed fully.

- Access. An indication of an appropriate access level based on a rigorous assessment of the member's actual or potential need and repayment capacity considering risks to the current and capital accounts. In particular, the assessment of a precautionary BoP need should include a discussion of one or more scenarios based on alternative assumptions about key parameters (external debt rollover rates, magnitude of portfolio outflows, etc.). This note should also include an assessment of the impact of the arrangement on Fund liquidity in cases where requested access would exceed 575 percent of quota or SDR 10 billion, whichever is lower.

- Tables. Standard economic indicators and a balance of payments table (both with projections for the current year and following year), and a table on gross external financing requirements and sources of finance under the baseline case and under an adverse scenario (if the arrangement is requested on a precautionary basis). For transparency when requesting a successor arrangement, the table showing the gross external financing requirements should make clear how current adverse shock assumptions compare to those under the previous arrangement. A table comparing access metrics across various cases should also be included (compared with previous FCL and exceptional access cases). Provided the requested access amount has been finalized, a capacity to repay table would be also included.

\section{B. Staff Report for the Formal Request for an FCL Arrangement}

2. The staff report should include:

- A discussion of recent macroeconomic developments and policies, the economic outlook, the expected evolution of risks over the arrangement period, and the authorities' forward-looking policy plans, including their exit expectations (as informed by discussions with the authorities). 
- A discussion of potential (or actual) sources of BoP pressures and other risks, building on the assessment already included in the staff note.

- A detailed assessment of the qualification criteria (including the material from the concise staff note and any additional information).

- As part of the above, a debt sustainability analysis including the evolution of debt, as well as rollover and financing requirements under alternative scenarios (including an assessment of contingent liabilities, where appropriate) and stress tests.

- A discussion and justification of the proposed access level.

- A discussion of the member's capacity to repay the Fund in the event that the member makes purchases under the FCL arrangement.

- Staff appraisal.

- Tables. Selected economic indicators including projections for the current year and following years to cover the length of the arrangement, a balance of payments table (ideally with projections for a five-year time span), tables on external financing requirements and sources and fiscal projections for the years of the arrangement, the debt sustainability tables (external and public), a table on capacity to repay the Fund, and a table illustrating alternative metrics for access.

- A draft proposed decision for approval of the $\mathrm{FCL}$ arrangement and the text of the $\mathrm{FCL}$ arrangement, both prepared by LEG.

- An assessment prepared by FIN on the impact of the proposed FCL arrangement on the Fund's finances and liquidity position, as a supplement to the staff report. ${ }^{1}$

- Authorities' written, signed communication.

C. Staff Report for the Mid-term Review

\section{The Mid-Term Review Staff Report should be concise, containing the following} sections:

- Recent economic developments (with a discussion about the role played by the $\mathrm{FCL}$ in dissipating tail risks as well as the expected evolution of risks-including on the basis of the latest WEO and GFSR-over the remainder of the arrangement period) and policies.

- Brief review of qualification criteria.

- Staff appraisal.

- Tables. Standard economic indicators for the current year and the following years to cover the length of the arrangement, a balance of payments table (ideally with projections for a five-year

\footnotetext{
${ }^{1}$ An example of this supplement is Mexico-Assessment of the Impact of the Proposed Flexible Credit Line Arrangement on the Fund's Finances and Liquidity Position (IMF Country Report No. 09/126). FIN staff will contact the mission team concerning data requirements.
} 
time span), tables on external financing requirements and sources and fiscal projections for the current year and following year, debt sustainability tables (external and public), and a table on capacity to repay the Fund. When requesting a successor arrangement, the external financing needs table should make clear how current adverse shock assumptions compare to those under the previous arrangement.

- A proposed decision to complete the review prepared by LEG.

- If there have been very substantial changes in policy strategies or goals, then a new, signed letter from the member setting out their new strategies and goals should also be attached and discussed in the report. 


\section{Annex VI. Expedited Procedures}

1. Although typical Fund arrangements, including those with Exceptional Access (EA), provide for expedited procedures with activation of the Emergency Financing Mechanism (EFM) if it is judged that following normal procedures could entail significant risk for the member, the EFM procedures do not apply to requests for FCL arrangements (FCL decision, paragraph 7). Instead, the FCL Decision itself sets out the expedited procedures to be followed, if necessary ( $F C L$ decision, paragraph $6(\mathrm{a})(\mathrm{v}))$. This would be clearly the case if a crisis were imminent or already underway, necessitating fast disbursement of Fund resources. However, it could also apply in cases where a crisis is not imminent (and the member does not intend to draw on approval) but where, against a backdrop of fragile financial conditions, there are serious concerns about possible leaks if the qualification process and determination of access is protracted, and the resulting uncertainty could send the opposite signals than what the $\mathrm{FCL}$ aims for. In such cases, a possible timetable could be as follows:

- Staff and management "engage" the Board on FCL qualification and proposed access level, on the basis of documentation provided to the Board at least two hours prior to the informal Board meeting "to engage" (analogous to what is stated in the Acting Chair's Summing UpReview of Access Policy Under the Credit Tranches and the Extended Fund Facility, and Access Policy in Capital Account Crises-Modifications to the Supplemental Reserve Facility and Follow-Up Issues Related to Exceptional Access Policy (Executive Board Meeting 03/16, February 26, 2003)).

- Directors would be consulted during the informal Board meeting on possible issuance of a press release indicating the authorities' interest and management's intention to recommend Board approval of the $\mathrm{FCL}$ arrangement. The press release would take special care not to prejudge the Board's exercise of its responsibility to take the final decision on an FCL arrangement. ${ }^{1}$

- A formal Board meeting could consider the member's request within 48 to 72 hours following the circulation of the staff reports to the Board (paragraph 6(a)(v)).

\footnotetext{
${ }^{1}$ This would be parallel to the EA policy (Acting Chair's Summing up from Executive Board Meeting 03/16, February 26 , 2003) which highlights that "Management will consult with the Board specifically before concluding discussions on a program and before any public statement on a proposed level of access. Strict confidentiality will need to be maintained, and public statements by members, staff, and management should take special care not to prejudge the Board's exercise of its responsibility to take the final decision." It would also be in line with past practice, whereby statements by management followed ad referendum agreement with the authorities.
} 


\title{
Annex VII. Synchronized Approval of Flexible Credit Lines for Multiple Countries'
}

\begin{abstract}
1. This annex sketches the procedures under which synchronized approval of FCL arrangements for multiple member countries could be undertaken under the existing FCL Decision and other Fund policies. When multiple members face the same shock, synchronized approval of FCL arrangements could strengthen the effectiveness of the response to the common shock and minimize first-mover problems. This annex neither modifies existing Fund policies, nor establishes a new financing instrument.
\end{abstract}

2. Synchronized FCLs: When hit by a common shock, member countries may approach the Fund jointly to request Fund financial assistance. Most likely, however, potential interest by members would be conveyed bilaterally. In any case, and as required under the $\mathrm{FCL}$ Decision, each member's qualification for the $\mathrm{FCL}$ would be assessed individually, and only after the member has affirmatively expressed interest in the FCL. More generally, FCL arrangements requested or approved on a synchronized basis are not different from other $F C L$ arrangements, and would be subject to all the requirements applicable under the FCL Decision and other Fund policies.

3. Confidentiality: Confidentiality must be preserved in discussing with members the potential use of, and qualification for, the $\mathrm{FCL}$, as required in the $\mathrm{FCL}$ Decision ( $\pi 6$ ). Only the Executive Board has the authority to determine qualification or to approve $\mathrm{FCL}$ arrangements, as recommended by management. With this in mind, in informal discussions with members, Fund staff and management would not confirm that any particular member would qualify for an $\mathrm{FCL}$ arrangement; neither would they reveal that any other member has expressed interest in the $\mathrm{FCL}$, unless the member(s) that has already expressed interest has agreed that such information can be shared in the informal discussions with other members.

4. Synchronized FCL procedures: Should a number of members express interest in synchronized financial assistance from the Fund under FCL arrangements, and Fund management decides that access to Fund resources under the FCL by each member may be appropriate, the Executive Board will be promptly consulted in an informal meeting. Expedited approval procedures could be followed consistent with the FCL Decision. ${ }^{2}$ This synchronized consideration and approval of FCL arrangements would be governed by the same policies and requirements currently in place under the FCL Decision to approve an FCL arrangement for each member, and by the standard procedures and practices governing matters such as the issuance of Board documents and the conduct of Board meetings.

\footnotetext{
${ }^{1}$ Based on Technical Note on Synchronized Approval of Flexible Credit Lines for Multiple Countries; IMF Policy Paper; November 12, 2010.

2 The FCL Decision ( $(6)(a)(v)$ ) states that the minimum periods applicable to the circulation of staff reports to the Executive Board shall apply to $\mathrm{FCL}$ arrangement requests, provided that the Executive Board will generally be prepared to consider a request within 48 to 72 hours after the circulation of the documentation in exceptional circumstances, such as an urgent actual balance of payments need.
} 
5. External communications: If there are concerns about a market-sensitive leak or misinformation about the $\mathrm{FCL}$ requests, management could issue a short press statement following the initial informal Board meeting indicating the concurrent request of $\mathrm{FCL}$ arrangements, provided the relevant members agree to it. The press statement will take special care not to prejudge the Board's exercise of its responsibility to take the final Decision on the FCL arrangements.

6. Access: As with other applicable FCL policies and requirements, the general Fund policies for duration and access under FCL arrangements will be followed when synchronized FCL approval procedures are used. Hence, proposed access levels would be based on a rigorous assessment of each member's actual or potential balance of payments need and capacity to repay, and would take into account the individual and cumulative impact of the access requests on Fund resources (I6(a)(iii)(I) and (II) of the FCL Decision).

7. Safeguards: Depending on the individual and collective size of the relevant arrangements, concurrently approved FCL arrangements could have important implications for Fund resources and liquidity management. The recently strengthened procedural requirements for early Board involvement in assessing the contemplated access and the impact of such access on Fund liquidity, in the context of other potential demand for Fund resources, are useful safeguards in this respect. To ensure early Executive Board consideration of the liquidity implications arising from concurrently approved FCL arrangements, staff intends, as an added safeguard, to include a liquidity assessment in the staff note (or notes) for the initial informal Board meeting whenever total access across the proposed arrangements would exceed SDR 10 billion, even if no individual arrangement contemplates access above this threshold. 